University of Rhode Island

DigitalCommons@URI

Open Access Master's Theses

1990

\title{
The Development of Augustine's View of the Freedom of the Will from Conversion to the Confessions
}

Gregory E. Ganssle

University of Rhode Island

Follow this and additional works at: https://digitalcommons.uri.edu/theses

\section{Recommended Citation}

Ganssle, Gregory E., "The Development of Augustine's View of the Freedom of the Will from Conversion to the Confessions" (1990). Open Access Master's Theses. Paper 1546.

https://digitalcommons.uri.edu/theses/1546

This Thesis is brought to you for free and open access by DigitalCommons@URI. It has been accepted for inclusion in Open Access Master's Theses by an authorized administrator of DigitalCommons@URI. For more information, please contact digitalcommons-group@uri.edu. 
THE DEVELOPMENT OF AUGUSTINE'S VIEN

OF THE FREसDOM OF THE WII

FROA CONVERSION TO

THE CONFESSIONS

BY

GREGORY E. GANSSLE

A THESIS SUBMIITHED IN PARTIAL FULFIIIMIMNT OF THE REOUIRENENIS FCR THE DEGRES OF

MASTHER OF ARIS

IN

PHIIOSOPHY

UNIVERSITY OF RHODE ISLAND

1990

\#22773000 
ABSTRACT

For much of his life, saint Augustine was preccoupied with concerns related to the freedom of the muan will. If one traces his view of the muman will throughout his life, one notices a significant development. In his early writings against the Manichaeans he maintained that the origin of evil can be traced to evil choice. At the very end of his life he came to defend the position that the mman will did not have the ability to turn to cod apart from divine intervention. In this study I demonstrate that Augustine's view of the freedom of the mman will underwent a significant development during the first decade after his conversion to Christianity (386-397). To demonstrate this, I outline his position as it is found in his works during three periods within this decade. The first period (386-391), before his ordination, is the period in which he held that the muan will has the freedom of indifference. In other words, it is possible for an individual to turn to God or to refuse to turn regardless of divine intervention. The second period (391-396), after his ordination and before his episcopacy, is the period in which, although still holding 
to the freedom of indifference, Augustine recognized to a much greater degree the struggle in the mman will. The third period is his early years as bishop (396-400). During this time, Augustine held that it is impossible for an individual to turn to God without divine intervention and it is impossible to refuse to turn, if such intervention was granted.

Finally, I briefly sketch three possible influences on this development. First, I show that it was Augustine's study of the Scriptures which was, probably, the principal influence. Next, I discuss how his own moral and spiritual struggle may have helped him realize the difficulty of making right moral choices. The third possible influence was his attempt at reforming the moral and spiritual lives of those in his congregation. These three factors may have helped Augustine recognize that it is only with the aid of divine intervention that an individual can turn to cod. 


\section{ACKAONLEDEMENISS}

There are several people who have made this project possible. First, I would like to thank Professor William Young of the Philosophy Department. Although he was not officially on $\mathrm{ml}$ committee, he has been extremely helpful though personal discussion of the issues this study raises. Next, I wish to thank the members of my committee. Professor Charles Daniel of the History Department has been a great help and encouragement, especially in narrowing my topic. Next, Professor John Peterson of the Philosophy Department has given time and comments which have helped me clarify my use of key terms. Finally, Professor Donald zeyl, has been my mentor philosophically. He has shaped my abilities and perspectives through the many classes I have had with bim and his help on this project has been extremely valuable. More than all of this, however, I appreciate his friendship.

My wonderful wife, Jeanie and our boys, David and Nick, have had the task of living with me as I agonized over this study. Their love and encouragement make life a joy beyond description. To Jeanie, this work, and all my work, is dedicated. 
CONIENIS

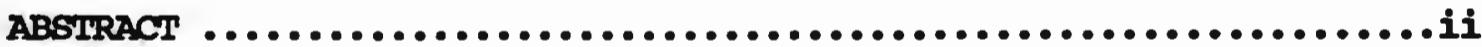

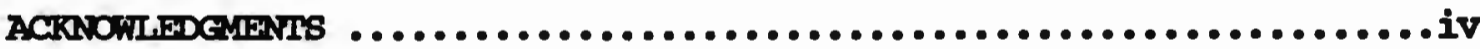
Chapter

I. INIRODUCIIION $\ldots \ldots \ldots \ldots \ldots \ldots \ldots \ldots \ldots \ldots \ldots \ldots \ldots \ldots \ldots \ldots \ldots \ldots \ldots \ldots \ldots \ldots \ldots$

II. AUGUSTINE'S VIEN OF THE FREFDOM OF THE WII

FROM CONVERSICN TO CRDINATICON ..........................16

III. ADGUSTINE'S VIEN OF THE FREFDOM OF THE WIIL

FROY CRDINATION TO EPISCOPACY ..........................43

IV. AUGUSTIIE'S VIEN OF THE FRHEDOM OF THE WIIL

TN THE EFARLY YEAARS OF EIIS EPISCOPACY $\ldots \ldots \ldots \ldots \ldots \ldots \ldots \ldots \ldots \ldots \ldots \ldots 77$

v. INIFLUENCFS CN THE DEVHOPMENT OF AUGUSTINE' 8

VIEA OF THE FREDDOM OF THE WIIL

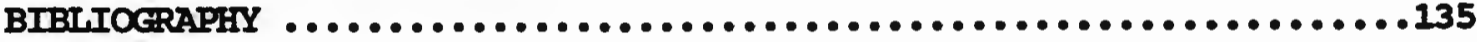




\section{CHAPTER ONE}

\section{INIRODUCIION}

Augustine was a man driven by the problem of the existence of evil in the world. This problem was the impetus for much of his work and thought. Each stage in his development was deeply influenced by the burning questions it raised. It drove him into Manichaeism and it was one of several issues that caused him to become disenchanted with it. His attraction to the Neo-Platonists was partly cue to the insight they brought to the nature of evil. These insights were carried into his Christian world-view, upon his conversion, and, although some of them remained intact throughout his life, others were gradually transformed into a more consistently Christian approach to the problem.

This transformation was not at all smooth. If the problem of evil served as a constant underlying force behind his thought, it was philosophical and theological controversy that was the anvil on which the specifics of his positions were contimously hammered out. As a result, a systematic exposition of Augustine's position on the problem of evil involves both a careful unraveling of themes which are embedded in specific polemical writings and a scrupulous consideration of chronology.

The two most important groups against which Augustine argued and which raised the problem of evil to the surface were the Manichees and 
the Pelagians. The Nanichees were a sect founded by Mani (d. 276). some of their more significant beliefs included a dualistic view of reality, especially of good and evil, an absolute repudiation of faith or any religious authority as being against reason, and an ascetic approach to religious practice.

It was the dualistic view of reality which presented an answer to the problem of evil. The Manichees believed that there existed two ultimate principles, the principle of Iight, or ormuzd (God) and the principle of Darkness, or Ahriman. ${ }^{1}$ These were equal in power. They were engaged in an eternal war with each other. These were not spiritual beings, (Manichaeism is fundamentally materialistic), but they were, respectively, the source of goodness and the source of evil. In muman nature, this dualism was ever present in that the body was a result of Evil and the soul (a material soul) derived fram the Good. The Manichees, accordingly, practiced asceticism, suppressing the body and anything related to the bodily appetites.

This account attracted Augustine as a solution to the riddle of evil, as well as for its high view of reason. As Peter Brown relates:

Only this group, Augustine thought, could answer the question that had begun to "torment" him as soon as his "conversion" to philosophy had caused him to think seriously: "From what cause do we do evil?" The Manichaean answer to the problem of evil is the core of the Nanichaeism of the young Augustine. ${ }^{2}$

1 See Frederick coplestion, A History of Philosophy: Medieval Philosophy: Augustine to sootus, Vol. II, (Westminster, Md.: The Newman Press, 1950), p. 41. Peter Brown, Augustine of Hippo (Berkeley: University of California Press, 1967), p. 46. 
Augustine followed the sect for nine years. Even toward the end of his association with them, he took comfort in their answers about evil; especially about the evil that was a part of his own experience. In the Confessiones he wrote:

For it still seemed to me "that it was not we that sin, but that I know not what other nature sinned in us." And it gratified my pride to be free from blame, and, after I had committed any fault, not to acknowledge that I had done any,- "that Thou mightest heal my soul because it had sinned against Thee;" but I loved to excuse it, and to accuse scmething else (I wot not what) which was with me, but was not $I$. But assuredly it was wholly I, and my impiety had divided me against myself. 3

Finally it was the very things for which he entered Manichaeism that prompted him to leave. His growing disillusionment regarding Manichaeism was prompted by, among other things, the inadequacy of their solution to the problem of evil. Portalie abserves, "The fact of the matter was that the problem of evil always bothered him and the more acquainted he became with Manichaeism, the less he was able to put his anxiety to rest. 104

Ultimately, Augustine remained puzzled; the dualistic solution turned out to be no solution at all. If Evil was just as powerful as Good, why should one prefer one to the other? If God was of such a nature that he could be thwarted by a material principle; and if, in fact, he has been eternally thwarted, certainly cod was not worthy of 3

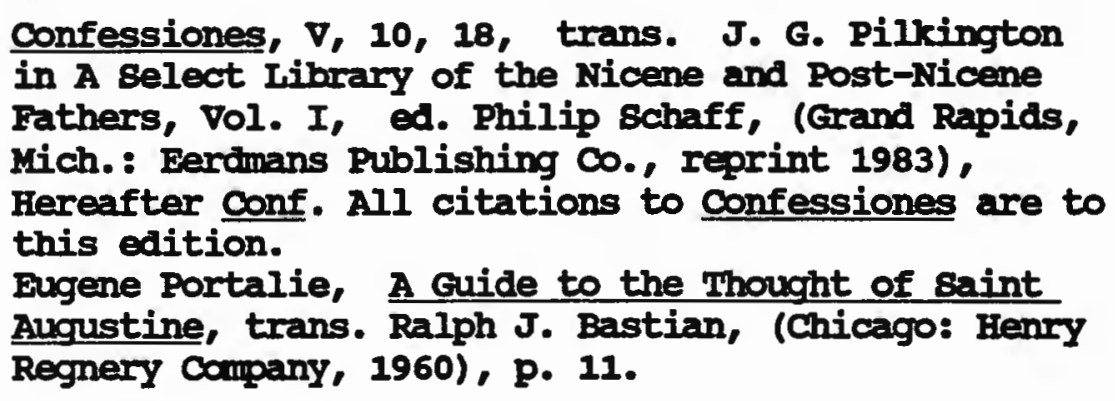
this edition. Eugene Portalie, A Guide to the Thought of saint Augustine, trans. Ralph J. Bastian, (Chicago: Henry Regnery Company, 1960), p. 11. 
devotion. Although disenchanted, Augustine held on to the sect hoping for better answers to come along. He drifted for a time into philosophical scepticism but in 386 he began reading some of the works of Plotimus. It was the thought of the Neo-Platonists that freed him from same of the dead-ends of Manichaeism.

specifically, in the context of the problem of evil, the Neo-Platonists suggested not only that Evil is not equal to Good lGod or the one) but that evil is not even a substance at all. It has no positive existence. It is but a lack, or a privation, of some good within a subject. This view allowed Augustine to see how God could be morally perfect and be the creator of everything without charging Him as the creator of evil. God did not create evil because evil is not a thing. "And I inquired what iniquity was, and ascertained it not to be a substance, but a perversion of the will,....15

The Neo-Platonists set the intellectual stage for Augustine's conversion to Christianity in late August of 386.6 As a Christian, Augustine's early work was strongly influenced by Neo-Platonic themes. After a very short time, he turned his literary attention to the sect from which he had emerged and launched a barrage of tracts, letters and books which eventually devastated the Manichees. In these works, his developing position on the origin, nature and role of evil was central.

One of the themes which emerges in these works is the freedcm of the individual will as the origin of evil. This is developed specifically in response to Manichaean determinism. Against the $\begin{array}{ll}5 & \text { Conf., VII, 16, 22. } \\ 6 & \text { See Peter Brown, p. } 74 .\end{array}$ 
Manichaean notion that the individual muan is a pawn in the cosmic struggle between the Good and the Evil Principles, Augustine posited the individual as being capable of and responsible for generating evil. Manichaeism held a strict determinism. The evil a man did was a direct result of the evil principle within him. As we have seen, this was worked out in Augustine's own life as an excuse for his conduct. He was blameless; the Evil Principle was blameworthy.

ance he had grasped the implications of Neo-Platonism and had become a Christian, he realized that each individual human being was responsible for the wrong he or she did. "Every man is the author of his evil deeds."7 Augustine locates the authorship of the evil deed in the man himself. It is, as Augustine argues below, the mind itself which freely chooses evil. The human will is completely unooerced in this evil choosing. Augustine writes:

So we are left with the conclusion that whatever is equal or superior to a ruling mind possessing virtue cannot make it serve lust because of its just character. And whatever is inferior cannot do it by reason of its weakness. So our argument teaches us: Nothing makes a mind a companion of cupidity, except its own will and free choice. 8

The origin of evil lay in the free choice of the will. It is this issue of the freedom of the human will that was the substance of the second major controversy for Augustine. This was the controversy with the Pelagians. Pelagius, originally from Britain, moved to Rome where

\footnotetext{
$7 \quad$ De libero arbitrio, I, i, 1 in Augustine: Earlier Fritings, trans. J.H.s. Burleigh, (Philadelphia: Westminster Press, 1953), Herefafter De lib arb. All references to De libero arbitrio are to this edition unless otherwise noted. Ibid., I, xi, 21.
} 
he joined in discussions on Paul. out of these came his book, Expositions of the Letters of saint paul. In the year 111, Augustine was made aware of the nature of Pelagius' views and he began to marshal arguments against what he considered to be heresy. The controversy lasted until Augustine's death. In fact, his last work is an incomplete work against Julian of Eclanum who was a follower of Pelagian thought.

Pelagians held that there is no such thing as original sin. The effect of the sin of Adam on subsequent generations is simply that of a bad example. Each person has a perfectly free will by which he or she can remain sinless. There is no bondage of the will and no need for any divine intervention. Grace, as Augustine understood grace, is totally unnecessary. Grace, for Pelagians, is very different; it includes the initial gift of free will as well as other gifts of God such as, the moral law, and Christ's example and forgiveness for past sins.

Against the Pelagians, Augustine emphasized original sin and the necessity for divine intervention in a person's life in order for that person to do any good deed or to have faith. In emphasizing original sin, Augustine was adamant that the effects of Adam's sin plagued subsequent generations. Not only was evil introduced into the mman race and guilt transmitted, but every individual's freedam is impaired by that first sin. While Adam had the unhindered freedom to sin or to not sin, apart from the grace of cod, all of the rest of bumanity is 
only free to sin. 9 Augustine admitted that even pagans could be virtuous. He insisted, however, that the virtues of pagans were also gifts from God. 10

of course the Pelagians denied that this could be called freedom at all. In fact they quoted passages out of De libero arbitrio and claimed that Augustine had previously supported their position. Although never unvilling to admit that his views on many subjects developed, Augustine denied that he ever held beliefs that were Pelagian. 11

Ever since Pelagius made the charge, the question has been raised as to whether or not Augustine's view of the freedan of the will had really changed so radically. It is evident that there was significant development but many charge that the "early Augustine" was completely contradicted by the "later Augustine".

In actuality, the real develogment of Augustine's view of muan freedim began shortly after he became a priest in 391. Kany of his later "Anti-Pelagian" themes were explicit long before he had ever

9 In Retractions, I, 8, 4 Augustine writes, "Unless this will, then, is freed by the grace of cod from this servitude by which it has been made 'servant of sin, '...., mortal men cannot live rightly and devoutly." trans. Sister Mary Inez Bogan in The Fathers of the Church, Vol. 60, (Washington D.C.:

10 Catholic University Press, 1968), Hereafter Retr. see Epistle, 138, 3, 17, trans. J. G. Cumningham in Philip schaff ed. The Nicene and Post-Nicene Fathers, Vol. I, First series (reprint Grand

11 Rapids, Mich.: Eerdmans 1983), Hereafter Ep. see Retr., I, 8, 3-6. In section 4 Augustine writes, "In these and similar statements of mine, because there was no mention of the grace of God, which was not the subject under discussion at the time, the Pelagians think or may think that we held their opinion. But they are mistaken in thinking this." 
heard of Pelagius. Although the controversy with the Pelagians occupied a great deal of Augustine's time and energy, he was basically defending and applying the position he had already worked out. Gilson writes:

[W] are inclined to consider useless the discussion of Pelagius' influence on his doctrine of liberty. How could his task of opposing Pelagian error possibly lead him to exaggerate the rights of grace and jecpardize free choice, if it is true that he never questioned free choice and if, moreover, he ascribed everything to grace since the day he read and understood st. Paul? st. Augustine was never to go any further because he went at once as far as one can go: Man can only do what God gives him the strength to do;... 12

Before we shall be able to recognize the develogment of Augustine's view of the freedom of the will, we shall have to gain a greater understanding of Augustine's use of his key terms. At first glance, the terms "will" and "choice" appear to be interchangeable. In fact, there is a slight difference in meaning. "Will" (voluntas) is used to refer to the moral individual himself. Devid sosher explains:

Augustine's definition [of "will"] points beyond choice to a whole movement or tendency or posture of the soul, of which individual choices are simply manifestations. It therefore follows from the definition that will is the individual himself, but the individual viewed as the source of all his thoughts, feelings and actions as well as of all his choices. However, when understood this way, will for 8t. Augustine finally and most importantly becomes almost synonymous with the notion of "moral self" or "moral personality," i.e., the individual as moral agent, because it is by reason of the quality of its thoughts, feelings, actions and choices that the self is judged to be morally good or bad. ${ }^{13}$

12 Etienne Gilson, The Christian Philosophy of saint Augustine, trans. L.E.M. Lynch (New York: Random House, 1960), p. 160. Hereafter, Gilson. David L. Mosher, "st. Augustine on Freedom," Crux Vol. XII (1974-75) p. 20. See also John M. Rist, "Augustine on Free will and Predestination," in Augustine: A collection of Critical Fssays ed. R. A. Markus (Garden City, N.Y.: Anchor Books, 1972), p. 220. 
The will, as the moral self, is free in that it is uncompelled or uncoerced. Nothing forces the will to act one way or another. If the movement of the will is one which merits either praise or blame, it must be a voluntary movement. Augustine points this out:

Moreover, unless the movement of the will towards this or that object is voluntary and within our power, a man would not be praiseworthy when he turns to the higher objects nor blameworthy when he turns to lower abjects, using his will like a hinge. ${ }^{4}$

In the often used phrase, "Free Choice," "Choice" (arbitrium) refers to "the deliberative and decision making role of the will in the life of the soul."15 This is free (liberum) in that it is uncompelled and therefore it is that for which the soul is morally accountable.

The view that the choice of the will is one for which the will is morally accountable because it is voluntary and uncoerced is a view to which both a compatibilist and an incompatibilist may agree. It may be scmething of an anachronism to use terms such as "compatibilism" and "incompatibilism" when referring to Augustine's position on the freedom of the will. This is because Augustine's concerns seem far removed from the concerns of those who are involved in the contemporary controversy over this issue. still, these terms can be useful to clarify an important distinction in Augustine.

In this study I shall use the term "incompatibilism" for the view 
that a choice between two options is free only if it is within the power of the individual to choose either of the two options without any change in antecedent conditions. This is scmetimes referred to as the freedom of indifference. It must be kept in mind that Augustine's central concern in discussing the freedom of the will is in moral and spiritual choices. The question is whether or not it is within the power of a person's will to turn to cod or to refrain from sinning. Accordingly when I shall discuss antecedent conditions, in the context of this study, I shall always be referring to the intervention of cod in a person's willing. In other words, is it within the power of a person's will to turn to cod without any intervention by God, or is cod's intervention a necessary antecedent condition of willing to turn to Him? An incompatibilist answer is that it is possible for a person's will to turn to cod without divine intervention. There are no antecedent conditions which must be introduced in order to enable the will to choose rightly.

By the term "compatibilism" I shall mean the view that divine intervention is both a necessary and sufficient antecedent condition in order for the will to be able to turn to God or to refrain fram sinning. Without this intervention the will can only choose to turn away from God. When God intervenes, a person cannot refuse to turn to Him.

The term "voluntary," however, is used differently by those who adhere to compatibilism and those adhering to incompatibilism. For the incompatibilist a choice is free if it is voluntary in the sense that it is one in which the person has the freedom of indifference, i.e., 
either of the two options is within the power of the individual.

The compatibilist will also insist that a choice is free in that it is voluntary. By "voluntary," however, he means that the choice is in accordance with the will even if the will does not have the ability to choose the other option, given no change in antecedent conditions. In this way a choice can be necessary (in that there was only one option within the power of the will) and it can be free (in accordance with the will) at the same time.

Augustine seems not to have differentiated between these positions in the use of his terminology. We shall see, however, that in his early writings, before his ordination, he seems to have held an incampatibilist position. The will is the cause of the choice while it is itself not caused by anything else. When the will chooses one option, it could have chosen the other option; even if every other antecedent condition was the same.

In his works immediately after his consecration as bishop (and long before the Pelagian controversy), Augustine lays a great deal more emphasis on God's grace as a necessary condition of the will's ability to choose the good in a given situation. While in many non-moral situations, perhaps, the will could have chosen either option without a change in antecedent conditions, in a moral choice the will does not have the capacity to choose both options. Only if cod's grace is present can the will choose rightly. The choice of good or evil is still voluntary but grace is necessary in order to choose the good. God's grace is also a sufficient condition in the will's choosing the 
good. If God intervenes by sending His grace, the will will turn to Him. It is not within the power of the individual to refuse to turn to God, if His grace is present. This is a version of compatibilism.

While the Kanichaean and Pelagian disputes are usually seen as the major controversies which gave impetus to duxgustine's writings on the Problem of Evil and the freedom of the will, there were other events and influences which shaped his thought as well. One of these was the change in his vocation and in his sense of personal calling curing the first decade after his conversion.

It is not insignificant that the most fundamental developments in Augustine's view of the freedam of the will occurred during the period in which his life calling underwent the most profound changes. He began his Christian life, in 386, with a vision to pursue a life of sheltered contemplation and study. By 391 he had been ordained priest and within a very short time, his bishop, Valerius, broke with accepted practice and allowed Augustine to preach. 'within two years, Valerius' new acquisition was patiently explaining the creed to the assembled Catholic bishops of Africa!"16 only two years after this, in 395, he was consecrated co-adjutor bishop. In 396 Valerius died and Augustine became bishop of Hippo, where he served until he died in 430 .

The writings which Augustine produced during this first decade after his conversion follow closely his sense of vocation and calling. The style of each book, the problems it develops and the methods employed to solve them all reflect the concerns uppermost in Augustine's mind at the time of writing. These concerns were dictated

16 Peter Brown, p. 139. 
largely by his vocation and how be perceived his life work.

In the early dialogues, we meet a very Neo-Platonic philosopher trying to reach the truth and the vision of God through an ascent of reason. In Book III of De libero arbitrio (written about 395) he is wrestling with the implications of a specifically biblical doctrine such as the fall. By 397 , in the work De diversis quaestionibus ad simplicianum, he is doing a serious exegetical study of one of the most difficult passages in Paul and he is attempting to relate the text to concerns about the freedom of the will.

My thesis, in this study, is that there was a very significant development in Augustine's view of the freedom of the will during this period. Auxgustine began by holding the incompatibilist position, as we have described it. By 397 he had come to hold the compatibilist view. God's grace came to be seen as a necessary and sufficient condition to the turning of an individual's will to God. Given the changes in Augustine's life through this period, there were three issues which, it may be suggested, may have influenced this develogment. The first of these is that Augustine, as a priest, began to study the scriptures more diligently than ever before. The responsibility of regularly preaching forced him to pore over the texts and try to grasp and commicate their meanings accurately.

The second possible influence was his own continuing struggle to live a holy life. His desire of an ascent of reason to a vision of cod, in this life, was rapidly shown to be only a dream. The reality of sin and sin's effect in the habits of the will became all too clear and may have caused him to see human freedom in a different light. 
A third influence may be suggested. Perhaps, in his desire to persuade his congregation to live holy lives, he was faced with, not only the sluggishness of his own will, but the moral difficulties of the average fourth century Christian. This was most likely the least powerful influence on his mind and it has been very rarely alluded to in the literature. Nevertheless, there is some reason to believe that this may have played a role in the development of Augustine's view of the freedom of the will.

To pursue this I shall first set out Augustine's early view of muman freedom, held from 386-391, especially as it is expounded in De libero arbitrio Book I. I shall also draw from other works of this same period. Next I shall explain the view he held between his ordination and his consecration as bishop (391-395), focussing on the second and third books of De libero arbitrio. After that I shall explain the later view Augustine expressed in De diversis quaestionibus ad simplicianum Book I, Question 2 (397). I shall also refer to the Confessiones. Once the differences in Augustine's positions are made clear, I shall briefly sketch each of the possible influences on this develogment, beginning with the influence of scripture. In this I shall discuss Augustine's treatment of the ninth chapter of Romans in three separate works, the Expositio quarundam propositiomm ex Epistola ad Romanos, the De diversis quaestionibus IXOXIII, and the De diversis quaestionibus ad simplicianum. The influence of his own moral struggle will be drawn from the confessiones and various letters. The influence of the struggle of his congregation will be illustrated from letters and sermons. 
I shall conclude that it may have been in response to these three influences that Augustine's view of buman freedom developed curing the period between his conversion in 386 and the writing of his Confessiones in 397. 
CARPIHR THO

AOGUSTINE'S VIEA OF THE FRHEDOM OF THE WIL

FROM CONVERSION TO ORDINATION

Augustine was converted to Christianity in August of $386 . .^{1}$ It is perhaps no exaggeration to say that the next few years of his life were shaped as mach by the life he left as by his new life as a Christian. This is true of both the content and the perspective of his earliest works. In fact, some of his pre-conversion influences remained throughout his life. There was also another way in which his philosophical history influenced his early years as a Christian. This was in his understanding of his own life calling.

Stories and rumors about Christian ascetics and monasteries ${ }^{2}$ combined with the Neo-Platonic teaching of the soul's ascent to fulfillment through contemplation ${ }^{3}$ forged Augustine's view of what constituted the best life for a Philosopher and Christian. This was the life of the mind. He would pursue a life in which he could be free to think, converse and contemplate. Augustine's plan, just prior to his conversion, is described by Brown:

For at least a year, Augustine had regarded some form of this life "in Philosophy" as the only possible life for himself. But he

1

2

3 see Peter Brown, p. 74. see Conf., VIII, 6, $14 \& 15$. Henry Chadwick, Auqustine (Oxford: Oxford Oniversity Press, 1986), p. 21. 
had intended to retire gracefully into such a life. He would marry a rich and, so he hoped, a well educated beiress. He would serve the short spell of routine administration required of a cultured local governor. supported by his wife's estates and protected by the senatorial privileges of a former acministrator, he yould have found himself free, in a few years, to follow his dream.

Upon his conversion, however, Augustine abandoned any plans of marriage. He still desired to "retreat" and devote himself exclusively to Philosophy. At the end of the term in which he taught rhetoric, Augustine retired to the estate of a friend at Cassiciacum where he was joined by faithful friends and students as well as his mother, Monica. Shortly thereafter, he resigned from his post as teacher of rhetoric and devoted himself to Philosophy. Recalling this same eleven years later in the Confessions, Augustine writes that Cassiciacum was, "where from the fever of the world we found rest in Thee,....15 Brown writes:

When Augustine retired to Cassiciacum, in september 386, he would have appeared to be following a long-established and delightful tradition: delivered from the cares of a public career, he was about to enter upon a life of creative leisure, dedicated to serious pursuits. This was the ancient ideal of "otium liberale", of a "cultured retirement"; and looking back upon this period of his life, Augustine could speak of it as a time of "Christianae vitae otium", a "Christian otium". This ideal was to form the background of Augustine's life from that time until his ordination as a priest, in 391.6

It was at this retreat that Augustine's first four books originated. These demonstrate the confidence he had in the philosophical methodology he had adopted. When he didn't have the particular answer for which he was searching, he writes as though the

\begin{tabular}{ll}
\hline 4 & Peter Brown, p. 116. \\
5 & Conf., IX, 3, 5. \\
6 & Peter Brown. p. 115.
\end{tabular}


answer is just out of his grasp. This confidence is also shown by the depth and difficulty of the topics which he tackled. Augustine refutes philosophical scepticism in Contra Academicos, investigates the nature of truth and of the human soul in the soliloquia, addresses the highest end of mman life in De beata vita, and writes on the place of evil in a universe created and sustained by God in De ordine.

At Easter in 387 Augustine and Alypius left Cassiciacum to be baptized by Ambrose in vilan. They never went back. Plans to return to Africa were pursued but a series of changes far greater than simply those of geography were on the horizon, beginning with the death of Monica. Aurgustine mourned privately and deeply.

There were delays in Rome (where be began to write De libero arbitrio) and Augustine's party did not reach Carthage in Africa until late 388. They settled on Augustine's family property in Thagaste as a conmmity still dedicated to study, contemplation and thought. However, as Peter Brown points out, there was a shifting focus:

Thagaste could never be another Cassiciacum. Even curing his stay in Rome, Augustine's writings show a new determination. From that time onwards, he intended to live a secluded life no longer, as in Milan, on the fringe of a society of intellectual laymen, but directly in the shadow of the organized life of the Catbolic Church.?

The two years in Thagaste were marked with the deaths of Augustine's close friend Nebridius and his own son, Adeodatus. These losses, in addition to the bitter controversy which raged between the local Catholics and Manichaeans, seemed to drive him into a more active 7 Peter Brown, p. 132. 
life. In 390 he rrites to coelestimus:

On how I wish that I could contimally say one thing to you! It is this: Iet us shake off the burden of umprofitable cares, and bear only those which are useful. For I do not know whether anything like complete exemption from care is to be hoped for in this world. 8

It was at Thagaste that several works were written and others begun. The earliest and most philosophical questions in the De diversis quaestionibus IXXXIII were written in this period. 9 In the work De Magistro, Augustine and Adeodatus converse on the meaning of signs and the relationship between words and reality. In De vera religione Augustine argues, against Manichaeism, that both authority and reason are means to truth and that the truth of Christianity is reasonable and compelling.

As if he sensed his future, Augustine purposely avoided towns which were in need of bishops in order to avoid being forced into the job. Then Augustine travelled to Hippo in 391 , he was secure in the knowledge that Hippo had a bishop. He was surprised to be ordained to the priesthood nearly by force.

Fram his conversion to his ordination, Augustine had attempted to carve out the kind of life that afforded study and contemplation. He was, however, increasingly thrust closer to active church life and to the center of the major theological controversies of his time. As we shall see in the next chapter, once he was ordained and he took on the 8

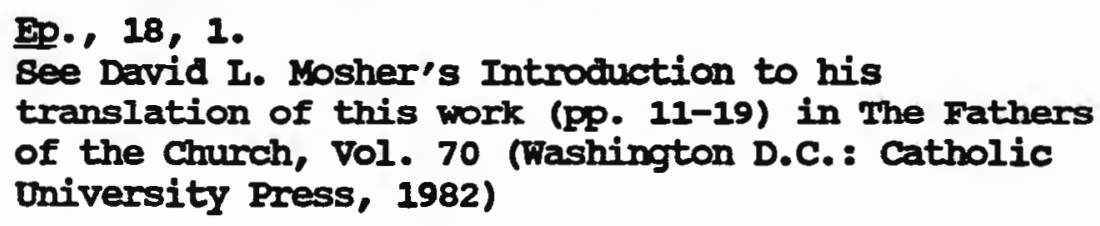


burden of the pastoral life, any time for leisurely study was squeezed out by his responsibilities to his new calling.

Augustine's View of the Freedcm of the will

in the Cassiciacum Dialogues

Not surprisingly, Augustine's earliest works bear the heaviest stamp of his Neo-Platonism. This is particularly evident in the subjects and methods with which he was preoccupied. In each of the four dialogs camposed or begun at cassiciacum, the central focus is general and speculative. Even when the topics intersect with the concerns of individual muan beings, they are dealt with in a universal and abstract manner.

In De ordine, for example, Augustine writes about the place of evil in a world controlled by God. This appears to be an issue which would elicit concern over and analysis of concrete situations. Instead the discussion remains very general. Even when the participants are distracted with a cock fight, ${ }^{10}$ they quickly move from specific observations to universal laws.

This same pattern is seen in the Boliloguia in which Augustine implores his own reason, "(Aug.) I desire to know God and the soul. (Reason) Nothing more? (Aug.) Nothing whatever."11 Although an investigation into the nature of the soul could bring up many issues 10 11 Hereafter De ord. De ordine, I, 8, 25 trans. Robert P. Russell in The Fathers of the Church, Vol. 5 (Ludwig schoopp, 1948), Soliloquia, I, ii, 7 trans. J. H. s. Burleigh in Augustine Earlier Writings (Philadelhia: Westminster Press, 1953), Hereafter sol. 
relating to particular human beings, Augustine's discussion begins and ends in the eternal and abstract.

It is not surprising, given the focus of these early dialogues, that Augustine does not address the freedom of the will in any detail. He made passing comments about the existence of free will but there is no position that is explicitly articulated, let alone defended. It is only as he confronted Manichaeism and he had to account for the origin of evil that he developed what could be considered a theory about the nature of muman freedom.

Augustine's acknowledgment of the existence of free will is seen in his introductory prayer in the soliloquia in which he comments that it is by God's laws that the soul is free:

In all that I say come to Iry aid, Thou who art alone God,... by whose laws, established forever, the unstable movement of mutable things is not permitted to be disordered, but is ever reduced to apparent stability by the reins which hold in the revolving ages; by whose laws the soul's will is free, and by unalterable necessity rewards are distributed to the good and pumishments to the evil. cod, from whom all good things flow down to us, and by whom all evil is warded off from us, above whom is nothing,... Hear me, my God. 12

In De beata vita, Augustine opens by explaining why so few people reach "the port of philosophy -from which, indeed, one enters to the hinterland of the happy life-."13 He briefly alludes to the existence of the will in the passing comment:

For, since God or nature or necessity or our own will, or a

12

13 sol., I, $i, 4$.

De beata vita, 1, 1 trans. Ludwig schopp in The Fathers of the Church, Vol. 5 (Ludwig schopp, 1948), Hereafter De bt vt. 
combination of some or all of these, would have us founder in this world heedlessly and by chance as in a stormy sea- the matter is indeed not clear,...14

Augustine says a little more in a passage in De ordine:

But who is so dull of mind that he will hesitate to attribute to divine power and divine govermment whatever there is of order in corporeal operations, apart from muan arrangement and will? ${ }^{15}$

From these brief references to free will, it is impossible to derive a full-fledged theory of muan freedom. It is not clear whether or not Augustine held to any theory at this time. He clearly believed in the existence of free will. He is emphasizing, in the De ordine, that God's providence over "corporeal operations" is complete up to, at least, the domain of mman freedom. Augustine says nothing, here, about the capacities or the nature of this will.

That there is no theory of free will in this work is significant in that evil is not linked to choice as in later works. Augustine does not even raise the question of evil's origin. It is divine order and providence that is his primary concern.

The Freedam of the Will in the works Immediately Beyond Cassiciacum

It is in the next few years that the freedom of the will becomes more important for Augustine. Bhortly after leaving Cassiciacum, Augustine wrote two pieces that followed in the style of the 
Cassiciacum dialogues. De immortalitate animae was written in 387 and De quantitate animae was written in 387-388. Augustine says little in either about the freedom of the will. There is, however, a statement concerning choice near the very end of De quantitate animae that does merit attention:

To the soul, indeed, is given free choice, and they who endeavor to undermine it with futile reasonings are so blind that they do not understand that of their own will they are voicing these absurd and impious statements. And the gift of free choice is such that, making use of it in any way whatever, the soul does not disturb any portion of divine order and law. It is conferred by the all wise and all prevailing Lord of all creation. 16

Augustine asserts two important statements in this passage. First, he asserts that it is obviously true that mumans are endowed with free choice. Choice is a gift to the soul. In fact, he claims, one could not argue against the existence of free will without choosing to so argue and thereby demonstrating that the will is free.

second, fugustine asserts that by the exercise of the will, a person cannot "disturb any portion of divine order and law." Just as we are cautious in attempting to extract a system from the one sentence in De ordine, it must be remembered that this too is a very brief comment; one not of sufficient length or depth to warrant the extraction of a full theory of the will.

It does seem, however, to be more clear than the other passage. The freedom of the will is given by God but it is somehow limited in what it can accomplish. It is not that Augustine is stating that the 16 De quantitate animae, 36,80 trans. John J. Mokahon in The Fathers of the Church, Vol. 4 (Iudwig schopp 1947), Hereafter De quant anim. 
divine will limits the options open to the mman will. Rather, he states that even when human beings make use of their wills in any way whatever, divine order is preserved. Augustine does not explain how the divine order takes into account any possible movement of the will. It is not that he is saying that God's order is decreed in response to the muman choosings. Nor is it that God's order eliminates any real freedom. somehow God's plan includes and is not hindered by the real choices people make.

It is not until Augustine engages in his anti-Kanichaean polemics that he articulates the relationship between the origin of evil and wrongful free choices. It is in this context that he is forced to develop and articulate a theory of muman freedom.

The Freedom of the Will in De Libero Arbitrio Book I

Augustine's treatise De libero arbitrio is the first of his works which include a clearly articulated position on the nature of man freedom. Augustine began to write it in Rome in 388 but did not complete it until 395.17 There was most likely a great time lapse between the writing of Book I and that of Book II. 18 The purpose of this work is well stated by Kaufiman:

The intention of Augustine's earliest treatise on free choice was not to explore the range of the will's operation (with or without divine assistance). The treatise was rather a rebuttal to the Manichaean argument that the God who created all things was 
responsible for the existence of evil. 19

Augustine, directing his attacks against the Manichaeans, thus emphasizes the privative nature of evil, that all created things are good in themselves and that evil has its origin in the misused freedom of the human will. It is out of these themes that a position on the nature of human freedom can be discovered.

Book I opens with Evodius asking, "whether cod be not the author of evil". 20 Augustine readily acknowledges that he already believes that God exists and that God is not responsible for evil. His investigation is to determine whether or not these things can be demonstrated by reason. Therefore he attempts to build or discover accounts of evil, responsibility, freedom and the will that are consistent with this position. Because, as Augustine assumes, God is just, only voluntary evil is punished. He writes, "God is not the author of the evil a man does though He is the author of the evil a man suffers." and "Every evil man is the author of his evil deeds."21

Evodius asks for the "cause why we do evil."22 In beginning to answer, Augustine acknowledges the difficulty of Evodius' problem:

[A]11 things that exist are from one cod; and yet cod is not the author of sins. The difficulty for the mind is this. If sins originate with souls which God has created, and which therefore have their origin from God, how are sins not to be charged against Note on the question of contimuity in Augustine's Understanding of Grace and Human Will," Alugustinian studies vol. 11 (1980) p. 59. 
cod at least mediately? ${ }^{23}$

Before one can discover why humans do evil, Augustine claims, one must grasp the nature, or the essence, of evil. What exactly is evil?, What is it that makes an act or thought evil? Augustine considers and rejects the views that what makes scmething evil is that it is a violation of a civil law and the view that an act is evil because of the lust which accompanies it. Evil, then, is discovered to be disorder, and goodness order.

Briefly to express in words as best I can the idea of eternal law as it is stamped upon our minds I should say this: it is just that all things should be in perfect order. 24

If the essence of goodness is perfect order, evil is disorder. Augustine takes this idea of perfect order and the complementary idea of disorder and applies them to human existence. Perfect order in man is defined as:

Whatever it is that puts man above the beasts, mind or spirit (perhaps it is best called by both names, for we find both in the divine scriptures), whatever it is called, if it dominates and rules the other parts of which man is composed, then a man is most perfectly ordered.

It is the reason of a man which should rule the rest of him. The question arises concerning whether or not it is even possible for reason so to rule. Perhaps scme other part of the nature of man, such as lust, is stronger or more dominant than reason. Augustine's response 
to this suggestion is that since it is true that the mind should rule, it must be stronger than lust. It would be inconsistent with good order for that which should rule to be weaker than that which should be ruled. For Augustine, reason is stronger than lust.

This position that the mind is stronger than lust (or any other vice) becomes an important premise in the argument that nothing forces the muman mind to do evil. Evil is freely chosen. If the mind is more powerful than lust and if virtue is more powerful than vice, "then no vicious [vice-filled] soul can overcome a soul armed with virtue."126 If a vicious soul cannot overcome a virtuous soul and force it to do evil, certainly, Augustine argues, no corporeal object (inferior to any soul in virtue of its corporeal nature) can force a virtuous soul to do evil either.

The only things more powerful than a virtuous soul would be other greater virtuous souls (God and angels). Although these have more power than a human soul, in light of their virtue, they would not influence a human soul for evil.

At present we can be sure that whatever it be that may rightly excel a mind strong in virtue, it cannot be unjust in any way. so that not even it, though it have the power, will compel a mind to serve lust....80 we are left with the conclusion that whatever is equal or superior to a ruling mind possessing virtue cannot make it serve lust because of its just character. And whatever is inferior cannot do it by reason of its weakness. So our argument teaches us: Nothing makes a mind a companion of cupidity, except its own will and free choice. 27

As Baboock explains, "The mind cannot be compelled either 
internally or externally. only the exercise of its own will, its own agency, can make it serve lust. It is, therefore, the author of its own evil."28 Augustine concludes that it is by the soul's own free choice, uncoerced by anything, that it wills evil. There is no outside compulsion which forces a soul to choose evil.

In the next brief section, however, Augustine argues that the souls of existing human beings are, in fact, not unhindered. The penalty of $\sin$ affects the very capacity to consistently choose correctly.

Is it to be regarded as in itself a small penalty that the soul is dominated by lust, spoiled of its resources of virtue, drawn hither and thither in abject poverty, now approving falsehood as if it were truth, now acting on the defensive, now rejecting what it had formerly approved but none the less falling into other falsehoods, now bolding its assent back, and often fearing the most abvious reasonings, now despairing of ever finding the truth and sticking in the dark pit of folly, now attempting to reach the light of intelligence, and again falling back in sheer weariness? Meantime the cupidities exercise their dominion tyrannically and disturb the man's whole mind and life with varying and contrary tempests, fear on one side, longing on the other; here anxiety, there vain and false rejoicing; here torture because something loved has been lost, there eagerness to obtain what it does not possess; here grief for injury suffered, there incitements to seek revenge. Wherever it turns it can be restricted by avarice, wasted by luxury, bound by ambition, inflated by pride, tortured by envy, enveloped in sloth, excited by wantonness, afflicted by subjection, suffering all the other countless emotions which inhabit and trouble the realm of lust. ${ }^{29}$

Augustine asserts that the present condition of the mum soul is not natural. It is the just penalty for sin. He asks of this, "can we think that a condition like that is not penal, when we see that Agency," The Journal of Religious Ethics Vol. 16 (Epring 1988) p. 35. De lib arb., I, xi, 22 . 
it must be undergone by all who do not cleave to visdam? ${ }^{30}$ The munan soul in its natural state is unhindered in its rule over the rest of the person. This natural state is how the soul was originally created by cod before sin entered the world. ance sin became a factor, both ignorance and impotence weighs down each mman soul.

Evodius, seeing this ignorance and impotence, argues that these can be the just penalty for sin only "if anybody placed on the height of wisdom should choose to descend and become a servant to lust."131 Only if the will of a person is umbindered could the choice to sin be called free or voluntary. If the weight of impotence was such that the person could not choose to be either good or evil, any subsequent penalty would be unjust. It seems, reports Evodius, that no person beyond the first had ever been free, in this sense, from the hindering effects of the penalty for sin. If this is the case, it seems that the human will is not free to avoid sin and any penalty is unjust.

Alugustine's response is that it is within the power of each individual to have a good will or not to have a good will. If one eagerly desires to be wise, one will have a good will. The very desire, when it is true, deep and when it governs the person's life is a good will.

You see, then, I imagine, that it is in the power of our will to enjoy or to be without so great and so true a good. For what is so completely within the power of the will as the will itself? Whoever has a good will has scmething which is far better than all earthly realms and all bodily pleasures. Whoever does not have it, lacks that which is more excellent than all the goods which are not in our power, and yet he can have it by willing it simply. 32 
Evodius' question was that he could not understand how it could be a just penalty for a soul which was never wise to be shackled by ignorance and impotence. Augustine's position is that even if one has never been wise, it is still within one's power to choose, here and now, to have a good will. This choice is, in essence, the choice to pursue wisdom eagerly. Ignorance and impotence, then, are the just penalty for refusing to have a good will and so to pursue wisdam. As Benjamin and Hackstaff translate:

Therefore, if we should love and embrace with our will the good will, and place it before all other things that we cannot keep even if we will to do so, then those virtues, as reason demonstrates, will dwell in our spirit, and to possess them is to live rightly and honorably. From this it is established that whoever wants to live rightly and honorably, if his will for this surpasses his will for temporal goods, achieves this great good so easily that to have what he wills is nothing other than the act of willing. 33

It is clear in this translation that wanting to live rightly is not enough. It is essential that one has a will for this which "surpasses his will for temporal goods." Once one has that will, it is easy to have what one wills because there is no difference between the act of willing and having what one wills. This is because one is

33

De lib arb. I, xiii, 29 trans. Anna 8. Benjamin and L. H. Hackstaff, (Indianapolis: Bobbs- Kerrill, 1964). This passage is labeled section 97 in this edition. 
already willing a good and honorable life. ${ }^{34}$

In this passage, it is unclear whether or not Augustine is explicitly asserting that it is within the power of a person's will, apart fram any divine intervention, to desire the right and honorable life enough to attain it. From the context, bowever, it can be concluded that Augustine bolds that we are justly held responsible for pursuing or refusing to pursue the good will.

If it is true that the good will can and should be pursued, the next question is, why is it that not every person is happy? Obviously every person wishes to be happy. Augustine, once again, points out the distinction between wishing and willing. One who wishes to be happy might still not will to have a good will because he might not be ready to accept the righteous standard of living which necessarily accompanies a good will.

It is not surprising that umbappy men do not obtain what they wish, that is, a happy life. For they do not at the same time wish its accompaniment, without which no one is worthy of it, and no one obtains it, that is to say a righteous life. ${ }^{35}$

To will a good will involves willing according to the eternal law which demands right living as a means to happiness. Many wish to be happy but do not will it because they refuse to will what is necessary in order to obtain it. Augustine explains:

34 It seens that Baboock ("Mugustine on sin and Moral Agency," p. 36) misunderstands this text. He states that living rightly is, first, to be preferred above all transient goods and, second, that it is immediately within our grasp. The text indicates that to prefer to live rightly is a condition for having a good will, which is itself the condition for achieving this good so easily. De lib arb., I, xiv, 30 . 
So when we say that men are umappy volumtarily, we do not mean that they want to be unhappy, but that their wills are in such a state that unhappiness must follow even against their will. So it is not inconsistent with our previous reasoning that all men wish to be happy but cannot be; for all do not wigh to live aright, and it is that wish that merits the happy life. ${ }^{36}$

It is impossible to "prefer [a good will] before all fugitive and transient goods" and at the same time not wish to live rightly. This is abvious. If the condition which is a prerequisite to achieving a good will is having a greater desire to live rightly than to attain temporal goods, it seems that this condition is within an individual's power of choice. That one cannot attain the good will without a surpassing willing to live rightly does not imply that one has not the power to will in this manner.

The fact that Augustine holds that we are justly punished for refusing to have such a desire demonstrates that it is within the individual's power of choice. This is especially evident when it is considered that Augustine is arguing directly against Evodius' suggestion that we are not justly held responsible for the failure to have this good will.

Augustine next begins a brief discussion on the natures of both the eternal law and the temporal law. This further develops his notions of the essence of evil. He writes that the eternal law, "bids us turn our love away from temporal things, to cleanse it and turn it towards eternal things." 37 corresponding to the two classes of things, the eternal and the temporal, there are two classes of men, "those who love 36 Ibid., I, 8v, 32. 
and pursue eternal things and those who pursue temporal things."138 This is a foreshadowing of a theme which will become prominent in De civitate Dei. Augustine emphasizes that it is the will of each individual which detecmines that which the individual will pursue.

What each one chooses to pursue and embrace is within the power of his will to determine. Will alone can drive the mind from its seat of authority and from the right course. And it is manifest that when anyone uses anything badly it is not the thing but the man that uses it badly that is to be blamed. 39

John Roth expounds on the nature of this choice:

To turn toward temporal things (for example, material wealth, political power, sensual pleasure) and to make them the focus of one's "Wltimate concern," to use Paul Tillich's term, is to concern oneself primarily with that which is changing and perishing, and hence of less reality, value, and sustaining power. In these circumstances, one may lose himself to dimensions of reality that stand lower on the hierarchical scale. 40

The essence of evil was initially located as disorder. This is further clarified and is now understood as disorder in the will of man. When a man chooses to pursue the temporal things rather than the eternal things which he was created to pursue, his will is in disorder.

Now we may give our minds to consider whether doing evil is anything else than to neglect eternal things which the mind itself perceives and enjoys and loves and cannot lose, and to pursue, as if they were great and wonderful, temporal things which are perceived by the body, the lowest part of mman nature, and can never be possessed with complete certainty. For in this class, it seems to me, all evil deeds, that is sins, are to be included. 41 Ibid., I, xvi, 34. John R. Roth, Problems of the Philosophy of Religion (scranton, Pa.: Chandler Publishing $C_{\text {., }}$ 1971), p. 23. De lib arb., I, xvi, 34. 
In Book I Augustine has argued that the will of a human being is unconstrained by any outside factors. A person freely chooses whether to pursue eternal things or to pursue temporal things. It is true, however, that, as a result of sin, the will is hindered. But this hinderance is not a compulsion to sin. It is possible for a person to choose a good will, but only if the person has a will to live rightly that surpasses his or her will for temporal goods. It is this willing to live rightly that is hindered by the penalty of sin. The hindrances which weigh down the will are the just penalty for sin and they do not totally eclipse the will's power to choose. When one chooses to pursue temporal things, one's will is evil. This is not that the will in its essence is evil but its choice was disordered and blameworthy. The essence of evil is this disorder in the will. In this way, evil finds its source in the free but wrong choice of man.

Roth outlines two implications that Augustine is seeking by this account:

There are at least two important implications present in this response. First, Augustine wants to make clear that there is nothing necessary about man's doing evil. The emphasis on free choice rules out the view that men had or have to do evil. Men do evil, but it results from free choices. second, the relation between human freedom and evil is an important factor in Augustine's denial that cod causes the evil that men do and experience at the hands of each other. The evil men do and experience from each other does have a cause, but the cause is to be found in the human will rather than in cod. 42

Nothing is within the power of an individual more than his own Roth, Problems of the Philosophy of Religion, p. 24. 
choice. Therefore, when one chooses evil, one is rightly considered blameworthy and one is justly punished.

The Freedom of the will in De Vera Religione

Another work from this period in which Augustine discusses the freedom of the will is De vera religione. This book was written in Thagaste in 390 and sent to Romaniamus with a cover letter. In this letter Augustine introduces it as a work written, "concerning the Catholic religion. 143

De vera religione is an anti-Manichaean work in which sugustine emphasizes a positive apologetic for catholic Christianity. He defends the use of Authority as a valid means to knowledge and explains the relationship between Authority and Reason. He also defends the Incarnation and how "Reason sees the created universe as pointing to God."14 It is in the context of these issues that Augustine makes several references to the freedom of the will. some of these reinforce themes which emerged in De libero arbitrio Book I.

The first theme is that of the efficacious nature of each person's will. There are two related points in this theme. First, each person has the capacity to choose his or her destiny. It is up to the individual to choose whether he will be a man of virtue or a man of vice. Augustine writes that, "On this floor everyone voluntarily makes $\overline{43}$ 44

Ep., 15, 1.

See J.H.S. Burleigh's Introduction to De vera religione (hereafter De ver rel.) in sugustine: Earlier Writings p. 224. All references to De ver rel. are to Burleigh's translation. 
himself either corn or chaff."45 Thether a man is "corn" (a good man) or "chaff" (one whose life is carnal) is a result of a volumtary choice. We shall see that this can be interpreted in different ways and that the different interpretations result in different notions of the volumtary nature of the free choice.

The second point follows from the first. This view of the volumtary nature of the individual's choice is essential in order to view a wrong choice, or sin, as blameable. Augustine argues:

If the defect we call sin overtook a man against his will, like a fever, the penalty which follows the sinner and is called condernation would rightly seem to be unjust. But in fact sin is so much a voluntary evil that it is not sin at all unless it is voluntary.... Iastly if it is not by the exercise of the will that we do wrong, no one at all is to be censured or warned.... therefore, it is by the will that sin is committed. And since there is no doubt that sins are committed, I cannot see that it can be doubted that souls have free choice in willing. God judged that men would serve him better if they served him freely. That could not be so if they served him by necessity and not by free will. 46

There is no just punishment of an act that is not voluntary. In order for the person to be responsible, it must be true that he or she has chosen the act. Augustine holds that this is true even in cases where there is strong persuasion. In order to be morally responsible, the person must choose to sin by his or her own will. He writes:

Man is said to have been persuaded by the wicked angel, but even so it was his will that consented. If he had consented by necessity, out to me that the Iatin text is better translated as, "On this floor everyone volumtarily is [rather than "makes himself"] either corn or chaff." De ver rel., xiv, 27. 
he would have been held guilty of no sin. 47

Another theme mentioned in De vera religione which reinforces Augustine's view of the freedom of the will is that of the nature of an evil choice. Contrary to the Manichaean notion that the body itself and any bodily pleasure is evil, Augustine asserts that the object of one's choice is not evil. This is because there is no evil substance at all. Rather, in a case of turning from the highest good to some lower good, it is the turning itself that is evil. The evil resides in the choice. Augustine writes:

There is therefore a good which it is sin for the rational soul to love because it belongs to a lower order of being. The sin is evil, not the substance that is sinfurly loved. ${ }^{48}$

All kinds of sin and all heresies have this pattern in common, according to Augustine.

This is the origin of all impiety of sinners who have been condermed for their sins. Not only do they wish to scrutinize the creation contrary to the commandment of cod, and to enjoy it rather than God's law and truth- that was the sin of the first man who misused his free will- but in their state of condemnation they also make this addition to their sin. They not only love but also serve the creature rather than the creator, and worship the parts of the creation from the loftiest to the lowliest. 19

In De vera religione, there is no developed doctrine of the inheritance of sin and moral difficulty from Adam. Although this was hinted at in De libero arbitrio Book I, this inheritance was not deemed

$\begin{array}{ll}47 & \text { Ibid., xiv, } 28 . \\ 48 & \text { Irid., xx, 38. } \\ 49 & \text { Ibid., xoxvii, } 68 .\end{array}$


devastating to the individual's will. There is moral difficulty, and the persuasion of satan but there is no compulsion. It is still "his will that consented. 1150

\section{Assessment}

In this early period, Augustine emphasizes the helpful distinction between voluntary evil and coerced or compelled evil. It is an essential part of his theory, in these works, that only volumtary evil can be considered sin and can be justly pumished.

At first glance, it seems that the fact that the choice is voluntary supports the view that in any given situation, an individual could have chosen to be evil or to not be evil. We observed 51 that whether a man is "corn" [a good man] or "Chaff" [one whose life is carnal] is a result of a voluntary choice.

This can, however, be understood in two different ways. The compatibilist interpretation is that, while a person's destiny is a result of voluntary choice, there were antecedent conditions which rendered that choice necessary. The choice was both volumtary and necessary. It was voluntary in that the person is "corn" in accordance with his will (not against his will). The choice was, at the same time, necessary because he could not have willed, given the present antecedent conditions, to be "chaff".

The incompatibilist interpretation, on the other hand, is that the choice was voluntary and not necessary. The particular man who chose to $\begin{array}{ll}50 & \text { Ibid., xiv, } 28 . \\ 51 & \text { See pages } 35,36 \text { above. }\end{array}$ 
be "corn" had it in his power to choose to be "chaff" even if every antecedent condition was identical in both cases. Both an incompatibilist and a compatibilist would bold that it is because the choice is voluntary that it is one for which the individual is morally accountable.

To determine which interpretation best fits Augustine's position at this point, we must observe that, in a compatibilist scheme, an act is free because it is voluntary. That is, it is free if it is done in accordance with the will. A voluntary act could be also a necessary act. "Voluntary" and "necessary" are not contrary to one another and, therefore, neither are "free" and "necessary". The contrary of a free action is one that is not voluntary, that is, one that is done against the will.

An incompatibilist also claims that a free act is one that is voluntary. However, a voluntary act cannot be, at the same time, a necessary act. "Voluntary" and "necessary" are contraries. Onless the person could have chosen either of the two cptions, the choice is not volumtary; it is necessary. A "necessary choice" is no choice at all.

As we look into the texts, we see that, at this point in his development, Augustine holds that "voluntary" and "necessary" are opposed to one another. An act cannot be both. In De vera religione Augustine writes:

If the defect we call sin overtook a man against his will, like a fever, the penalty wich follows the sinner and is called condemnation would rightly seem to be unjust. But in fact sin is so much a volumtary evil that it is not sin at all unless it is voluntary. 52 
Man is said to have been persuaded by the wicked angel, but even so it was his will that consented. If he had consented by necessity, he would have been held guilty of no sin. 53

Clearly, in these passages, Augustine is opposing a necessary act and an act for which a person could be held blameworthy, that is, a voluntary act. This is a fairly clear statement of the incompatibilist position. In another passage, fram De libero arbitrio, Augustine brings out that the will has it in its power to choose either alternative:

You see, then, I imagine, that it is in the power of our will to enjoy or to be without so great and so true a good. For what is so completely within the power of the will as the will itself? Thoever has a good will has scmething which is far better than all earthly realms and all bodily pleasures. Whoever does not have it, lacks that which is more excellent than all the goods which are not in our power, and yet he can have it by willing it simply. 54

He asserts that it is in the power of the will to attain a good will or not to attain it. No mention is made of any differences in the antecedent conditions that would be necessary before the will could attain the other option. Again, in this passage, Augustine points out that all the person needs is to will in order to attain the good will. It seems clear that Augustine is saying that a person has it within his or her power to attain either of the two options regardless of any consideration of antecedent conditions. In fact, the whole tenor of this passage is to emphasize that by merely "willing it simply"55 the individual can actualize either of the two options. This is also closer 
to an incoupatibilist notion of the freedom of the will than it is to a compatibilist view.

\section{Summary}

In the period between Augustine's conversion and his ordination to the priesthood (386-391) he articulates a theory of the freedom of the will of which there are four major ingredients. The first is that each muman will has the ability to choose either evil or good. A person is not compelled to choose one or the other. Two important assertions follow from this. These are that it is part of the essential nature of sin that it be voluntary and that it is possible for a muan will to choose a good will and obtain it. The second ingredient is that, as a result of $\sin$ (and primarily the sin of the individual), the will is hindered in its choices. Fach soul is weighed down by ignorance and impotence. These do not remove the possibility of choosing or abtaining the good, but sin bas brought disorder to the soul in that reason no longer rules the whole of the person.

The third ingredient is that evil is located in the disordered willing of the soul rather than in the object of the willing. To love and desire same lower good in the place of the highest good is the essence of an evil willing. Fourth, in these works, there is little mention of the grace of cod as necessary to enable the will to choose rightly. At this point, Augustine's intention is not to establish the role of grace at all. It seems as though he suggests that the mum will is able to choose rightly without the special intervention of cod. 
As we have seen, Augustine's position during this period can be characterized as an inocmpatibilist position.

There are three aspects of Augustine's view of the freedom of the will which will develop throughout the next six years. The first is his view of the ability of the will to choose rightly. The second is his position regarding the depth of the effect of Adam's sin on this ability. The third is his view of both the necessity and the sufficiency of God's grace for right willing. As we shall see, Augustine will hold to the necessity of God's grace as an antecedent condition of willing rightly. This is a compatibilist view in that the will does not have the power to choose either of the possible options without a difference in antecedent conditions. The transition towards this view will begin shortly after his ordination to the priesthood in 391. 
CAAPIER III

\section{AUGUSTINE'S VIEN OF THE FRHADON OF THE WILI FROM ORDINATION TO EPISCOPACY}

It was in the spring of $391^{1}$ that Augustine traveled to Hippo in order to found a monastery. As we have mentioned, 2 Augustine purposely avoided those towns in which there was no Catholic bishop for fear of being consecrated bishop by force. Hippo, having its own bishop, valerius, seemed safe.

It was Valerius who, in a semon, expressed the desperate needs of the church so powerfully that the congregation leaped into action. seeing augustine in the back of the church, they forcibly aragged him to the front and presented him for ordination. Augustine immediately burst into tears. Those present supposed it was because he bad aspired to the higher office of bishop and now had to settle for being a priest. Augustine, however, was overwhelmed with both the difficulty of the priestly calling and the rashness of his former habit of criticizing priests and bishops. 3

Twenty-five years later Augustine recalled that day:

\begin{tabular}{ll}
\hline 1 & see Peter Brown, p. 74. \\
2 & see p. 19 above. \\
3 & See E. . 21, 2.
\end{tabular}


I, whom you see, with God's grace, as your bishop- I came as a young man to this city, as many of you know. I was looking for a place to set up a monastery, to live with my "mrethren". I had given up all hope in this world. What I could have been, I wished not to be: nor did I seek to be what I am now. For I chose to be mumble in the house of my God rather than to live in the tents of sinners. I kept apart from those who loved the world: but I did not think myself equal to those who ruled over congregations. At the Lord's Feast, I did not take up a higher position, but cbose a lower and more retiring place: and it pleased the Iord to say "Rise up'.

I feared the office of a bishop to such an extent that, as soon as my reputation came to matter among "servants of cod", I would not go to any place where I knew there was no bishop. I was on my guard against this: I did what I could to seek salvation in a muble position rather than be in danger in bigh office. But, as I said, a slave may not contradict his Lord. I came to this city to see a friend, whom I thought I might gain for God, that he might live with us in the monastery. I felt secure, for the place already had a bishop. I was grabbed. I was made a priest... and from there, I became your bishop.

Almost immediately, Augustine was thrown into what he describes as an "arduous work which now disquiets and crushes my spirit."5 seeing his own inadequacy, he wrote to Valerius pleading for a short period of time in which he could concentrate on the study of scripture. He writes of the fact that it is his own spiritual life that needs healing and growth as well as of the need he has to grasp how to minister to others in such a way that they too attain salvation:

[w] hen I have learned my infirmity, my cuty is to study with diligence all the remedies which the scriptures contain for such a case as mine, and to make it my business by prayer and reading to secure that my soul be endued with the health and vigor necessary for labors so responsible. 6

\footnotetext{
5 Sermon, 355, 2, cited in Peter Brown, p. 138. $5 \quad$ Ep., 21, 3.

6 Iria.
} 
But my difficulty is in the question how I am to use this truth in ministering to the salvation of others, seeking what is profitable not for myself alone, but for many, that they may be saved.?

The intensity of Augustine's pleading for this time of preparation demonstrates that he viewed his ordination as a turning point in his life calling. Even though he had been moving closer to an active life in the Church, ordination radically changed his focus. No longer did he have the freedom to pursue his dream of a monastery on his own terms. He was now a servant of the people of Hippo. Their needs came first and the pastoral ministry occupied the greater part of his attention.

Augustine did not have to give up the monastery, however. valerius graciously and wisely allowed him to develop it. He even gave Augustine the use of the garden on the church property for a location. Although this may appear to have been a concession on valerius' part, it was to his credit that he allowed this and other breaks with tradition. As Peter Brown observes, "He, therefore, ensured both that this umprecedented institution [the monastery] was officially recognized in Africa, and that a group of extraordinary men- many of them former Manichees- should settle in his town. ${ }^{8}$

There were two other ways in which Valerius broke with the accepted practice. The first was that he allowed Augustine to preach. up to this time, this privilege had been reserved for the bishops. It was in 393, while Augustine was still only a priest, that he was invited by Aurelius to address the assembled bishops of Africa on the 8 Trid., 21, 4. 140. 
Creed. 9 This message was published as De fide et symbolo. This invitation indicates the growing extent of Augustine's influence throughout the Cmurch in Africa.

The second break with tradition occurred in 395 when valerius had Augustine consecrated as axxiliary bishop. ${ }^{10}$ This prevented any other town that might be in need of a bishop from anatahing him into service. Valerius' action was effective in that Augustine served Hippo as ruling bishop from Valerius' death in 396 to Augustine's own in 430.

The Catholic Church of Hippo in 391 was besieged by heretics and schismatics. The heretics were the Nanichees. Augustine, already a veteran of many disputes with this sect, turned his attack to the Manichees at a local level. In 392, he challenged Fortumatus, a prominent member, to a public debate. Fortumatus was no match for the breadth of knowledge and skill in dialectics which Augustine wielded. After two days he was forced to leave town. The text of this debate is recorded in Acta contra Fortunatum Manichaeum.

The schismatics which threatened the church were the Donatists who claimed that they were the true church of Jesus Christ. According to this group, the Catholic bishops were spiritually descended (through consecration) from bishops who had collaborated in the Persecution of Diocletian in 303-305. 11 The acts of collaboration deprived the bishops of any spiritual authority or power. Those they "consecrated", according to the Donatists, were not true bishops. The Donatist bishops, in contrast, were spiritually descended from Donatus who had

\begin{tabular}{l}
\hline See J.H.s. Burleigh's Introduction to Faith and the \\
Creed, in Augustine: Earlier Fritings, p. 351. \\
$10 \quad$ See Copleston, A History of Philosophy, Vol. II, p. \\
11 Peter Brom, p. 215.
\end{tabular}


been consecrated by the very bishop who had been elected to replace the collaborators.

Augustine's many works against the Donatist position do not immediately concern the freedom of the will. However, it is important to keep in mind that, from his first days as a priest, Augustine was embroiled in two major controversies each of which independently threatened the survival of the small Catholic commmity at Hippo.

The effect of these controversies, his normal pastoral work and the establishment of the monastery left very little leisure time for literary writing. Although Augustine produced a momumental muber of books, it is no exaggeration to say that every one was influenced by same immediate controversy. Most of them were written specifically to meet some particular challenge.

It is in this context that Augustine completed Books II and III of De libero arbitrio. He also turned his attention to the writings of st. Paul. He began a commentary on Romans, which was soon abandoned and he circulated a work consisting of brief comments on selected passages in that book. This was the Expositio 84 propositiomm Epistolae ad Romanos. He preached many sermons including those that were collected into De sermone Damini in monte.

This period, between ordination and consecration, was one of transition for Alugustine. He planted himself in Hippo and took on his pastoral ministry with great effort. He became a preacher and a leader of common, uneducated men and women. He also developed into a theologian and an exegete as his works became increasingly focussed on the scripture. All of this had effects on his position regarding the 
freedom of the will. In this chapter I shall draw out the position Augustine held curing this period by excmining both Acta contra Fortumatum Yanichaerm and De libero arbitrio Books II and III.

\section{The Freedom of the will in Acta contra}

\section{Fortunatum Manichaeum}

It was in late August or early september of 392 that the public debate was held between Fortumatus and Augustine. 12 The debate lasted two days. Although Fortumatus tried to keep the discussion on ground which he considered safe, that is, the morals of Manichaeans, Augustine eventually succeeded in pressing his doctrinal criticisms of the sect. The discussion ranged over many issues, including the inviolable nature of cod, the origin and purpose of the soul, and the origin of evil. In the context of the origin of evil, the freedam of the will is discussed.

Against Fortunatus' dualism, Augustine contended that 'God made all things good, and ordered them well; but He did not make sin,..."13 In contrast, Fortunatus declared that evil was "apart from cod."14 By this he meant that evil was a substance distinct from cod. Augustine traced the origin of evil, again, to the choice of the will. sin by definition, is voluntary.

12 Peter Brown gives the date August 28 (see p. 141). The text of Acta contra Fortunatum Nanichaeum gives the date september 5. See the translation by albert H. Newman in A select Ifibrary of the Nicene and Fost-Nicene Fathers, ed. Philip schaff, Vol. IV, (Grand Rapids, Mich.: Eerdmans Publishing, 1983)

13 Hereafter C Fort.

14 C Fort. 15 Ibid., 16. 
I ask you, therefore, according to that passage which has been read [Ephesians 2:1-18], how can we have sins if contrary nature compels us to do what we do? For he who is compelled by nature to do anything, does not sin. But he who sins, sins by free will. Wherefore would repentance be enjoined upon us, if we have done nothing evil, but only the race of darkness? Iikewise, I ask, to whom is forgiveness of sins granted, to us or to the race of darkness? If to the race of darkness, their race will also reign with Him, receiving the forgiveness of sin; but if to us it is manifest that we have sinned voluntarily. For it is the height of folly for him to be pardoned who has done no exil. But he has done no evil, who has done nothing of his own will. 15

In another place, Augustine adds:

For if anyone, so to speak, should be bound by scmeone in his other members, and with his hand scmething false should be written without his own will, I ask whether if this were laid open before a judge, he could condem this one for the crime of falsehood.

Wherefore, if it is manifest that there is no sin where there is not free exercise of the will, I wish to hear what evil the soul which you call either part, or power, or word, or something else, of God, has done, that it should be punished by God, or repent of sin, or merit forgiveness, since it has in no way sinned? ${ }^{16}$

In response to Augustine's discussion of the freedom of the will, Fortumatus brings up that, in human experience, choosing does not seem to be as free as Augustine implies. In addition, he brings in certain New Testament scriptures which seem to support that the individual is powerless in the struggle against sin. He argues:

Therefore it is evident from these things that the good soul seems to sin not voluntarily, but by the doing of that which is not subject to the law of cod. For it likewise follows that "the flesh lusteth against the spirit and the spirit against the flesh; so that ye may not do the things that ye will." Again: "I see another law in my members, warring against the law of my mind and leading me captive in the law of sin and of death. Therefore I am a miserable man; who shall deliver me from the body of this death, unless it be the grace of God through our Iord Jesus Christ,"

$\begin{array}{ll}15 & \text { Tbid., } 17 . \\ 16 & \text { Tbid., } 20 .\end{array}$


"through whom the world has been crucified to me and I to the world?:17

It appears, reasons Fortumatus, that the will is not free in the sense that Augustine has been asserting. Both mman experience and the New Testament show that choosing rightly is difficult, if it is possible at all. Auxustine responds by discussing the role of habit (consuetudo) in the exsercise of the free choice of the will.

I say that there was free exercise of will in that man who was first formed. He was so made that absolutely nothing could resist his will, if he had willed to keep the precepts of God. But after he voluntarily sinned, we who have descended from his stock were plunged into necessity. But each one of us can find out by a little consideration that what I say is true. For today in our actions before we are implicated by any habit, we have free choice of doing anything or not doing it. But when by that liberty we have done something and the pernicious sweetness and pleasure of that deed has taken hold upon the mind, by its own habit the mind is so implicated that afterwards it cannot conquer what by sinning it has fashioned for itself. 18

Prendiville explains this necessity:

Adam, he explains, possessed free will. He was so made that if he willed to observe God's commands, nothing could resist his will. But after he sinned (and that by an act of his free will), we, his descendants, were thrown into a certain "necessity." We can verify this "necessity" for ourselves. Today, before we acquire a habit, we have the free choice to do a certain action or not. When, however, we have done samething freely, and the pernicious sweetness and pleasure of the action has gripped our soul, then it becomes so involved in its babit, that later it cannot gvercome what it made for itself by sinning in the first place. ${ }^{19}$ Ibid., 22.

19 John G. Prendiville, "The Development of the Idea of Habit in the Thought of saint Augustine," Traditio, Vol. 28 (1972) p. 69. 
The "necessity" into which we are thrown in virtue of being Adam's descendants is not that of being completely and inherently incapable of choosing rightly or wrongly. It is a necessity the experience of which each person brings upon himself or herself. Before twe are implicated in any habit" there is the freedom of indifference in doing or in refraining from doing any given action. Once an option is chosen, there is a resulting effect of the choice in the mind. In same cases, this is a deep attraction; what Augustine called a "pernicious sweetness and pleasure." once it is experienced, the mind is attracted and it forms the habit of choosing the option which brings this pleasure. The effect of this habit is a strong inclination to choose in one way rather than another. It is this inclination that Augustine calls a "necessity." It is important to keep in mind that what is inherited as a result of Adam's sin is the disposition to form these habits of the soul and to be bound by them. The necessity itself is not inherited.

In response to Fortunatus' use of the passage, "The mind of the flesh is hostile to cod; is not subject to the law of God, neither indeed can be,"120 Augustine further describes the effect of babit on the will's capacity to choose:

And this is what wars against the soul, habit formed in the flesh. This is indeed the mind of the flesh, which, as long as it cannot thus be subject to the law of cod, so long is it the mind of the flesh; but when the soul has been illuminated it ceases to be the mind of the flesh. For thus it is said the mind of the flesh cannot be subject to the law of God, just as if it were said, that snow cannot be wame. For as long as it is snow, it can in no way be warm. But as the snow is melted by heat, so that it may become warm, so the mind of the flesh, that is, habit formed with the flesh, when our mind has become illuminated, that is, when God has subjected for Himself the whole man to the choice of the divine

C Fort., 21 quoting Romans 8:7. 
law, instead of the evil habit of the soul, makes a good habit. Accordingly it is most truly said by the lord of the two trees, the one good and the other evil, which you have called to mind, that they have their own fruits; that is, neither can the good tree yield evil fruit, nor the evil tree good fruit, but so long as it is evil. Iet us take two men, a good and a bad. As long as he is good, he cannot yield evil fruit; as long as he is bad he cannot yield good fruit. But that you my know that these two trees are so placed by the Iord, that free choice may be there signified, that these two trees are not natures but our wills, He Himself says in the gospel: "Either make the tree good or make the tree evil." Who is it that can make nature? If therefore are commanded to make a tree either good or evil, it is ours to choose what we will. ${ }^{21}$

As long as the mind remains the mind of the flesh, nugustine reasons, it cannot be subject to God. This is not stating, as Fortunatus wished to imply, that the mind of the flesh can never be free to choose. Rather it is only as long as the mind remains of the flesh that it is bound by necessity. Once the soul has been illuminated, it is no longer the mind of the flesh. It is freed from the habits of evil and becomes subject to good habit.

Augustine clarifies the distinction between his view and that of Fortumatus by explaining the two trees. That they are wills and not natures can be seen because of the command to make them either good or evil. It is not within a person's power to change or to make his or her own nature. Therefore, the trees must represent wills. Because they are wills, it is clear that the source of evil fruit is the will and not the nature. This directly challenges Fortumatus' notion that the evil fruit is a necessary result of the dark nature within humans which derived fram the evil principle.

Prendiville sumarizes the role of habit in Augustine's thought at this time:

21 Tbid., 22 .


Thus by 394 one finds Augustine in kind of a half-way position between the thought of the De Vera Religione and the confessions. The ideas that he is emphasizing are these: Nan's will is free; any necessity toward evil that he experiences is the result of bad habits which he freely develops; this development is possible because he is a complex being, made up of body and soul; he can rid himself of these habits with cod's help and his own efforts, and thus attain peace even in this life. $22^{2}$

\author{
The Freedom of the will in De Libero \\ Arbitrio Books II \& III
}

\title{
De Libero Arbitrio Book II
}

Book II of De libero arbitrio centers on the question of whether or not cod should have given free will to man. Augustine's strategy of Book II is, first, to demonstrate that cod does exist and that this can be known by reason and not just by faith. secondly, he will argue that all good things that exist are from cod. Third, he reasons that free will is itself a good thing. If it is a good thing, and all good things come from God, then we know that it is from cod and that it is right that He gave it to us. Therefore cod is not to be blamed for evil because it was right that he should give us free will even though we use it to do evil.

Augustine's arguments for the existence of cod are interesting but do not, in themselves, concern us in this study. It is enough to observe that he is confident, both in virtue of his faith and in virtue 22 John G. Prendiville, "The Development of the Idea of Habit in the Thought of saint Augustine," p. 74. 
of his reason, that God does exist. His concern is, given that God exists, how we can answer the question of the origin and nature of evil in such a way that does not include making cod morally blameworthy for the evil in the world. He is attempting to discover notions of freedom, blameworthiness, evil and God's sovereignty which render his theistic view consistent. Once Augustine has demonstrated the existence of cod (at least to his own and Evodius' satisfaction), he moves on to the next step, that of demonstrating that all good things come from cod. Augustine claims that in the metaphysical structure of each individual thing is an essential dependence upon God for existence. All things, in so far as they exist, are from God. If all things are from God, certainly all good things, in so far as they exist, also are from God. Augustine writes, "There can be no good things, whether great or small, which do not owe their existence to cod."23 Although all things owe their existence to cod, as we have seen, evil is not from God. By understanding that evil is not a positive thing and that it has no form, Augustine can coherently hold that every existing thing receives its form from god and is good. It can be said that God created everything but that He did not create evil because evil is not a thing.

Once it is established that cod does exist and that He made every thing that is good, it must next be demonstrated that free will is to be considered a good thing. If free will can be shown to be a good thing, it can then be known that it has been given by God and that there is no reason to regret its having been given.

Augustine pursues two lines of thought in order to establish that 23 De lib arb., II, xvii, 46. 
free will is indeed a good thing. First, be shows that the fact that free will can be used for evil does not preclude its being good in itself. Augustine appeals to the human hand which no one considers an evil thing in itself even though it is possible, and even common, for one to use one's hand to do evil. If even a physical object, like the hand, can be good in spite of its potential use for evil, bow much more can an incorporeal thing such as free will be considered good?

The second line of reasoning Augustine presents is that there are mumerous things (such as the hair on one's head) which are considered good although they are not necessary in order for one to live a virtuous life. Since free will is necessary for a virtuous life, it must be considered a good thing.

What perversity it is to number our hairs among the good things though they are small and utterly contemptible, and to attribute their creation to God, the Creator of all good things because all good things, the greatest and the least, come from him from whom is all good; and yet to hesitate to ascribe free will to him, seeing that without it no one can live aright even on the testimony of those who live evil lives. 24

Augustine recognizes that there is a distinction between goods. There are goods, such as justice, which are called great goods. These can never be used for evil. Free will belongs to the class of goods called intermediate goods. These can be used either for good or for evil but they are good in themselves.

To use an intermediate good for evil is not to choose scme evil thing. It is, as we have seen, an evil choosing. It is to turn away from the highest good and to turn to a lower good. It is the turning 24 Ibid., II, xviii, 49. 
itself which is evil, not the lower good to which the will is turned. Nor is it the capacity to turn that is itself evil.

So it happens that the good things sought by sinners cannot in any way be bad, nor can free will be bad, for we found that it was to be mumbered among the intermediate goods. What is bad is its turning away from the unchangeable good and its turning to changeable goods. That "aversion" and "conversion" is voluntary and not coerced. 25

If it is this turning of the will that is evil, the nest question is what the cause of this turning could be. Augustine briefly touches upon this as a transition to Book III:

But perhaps you are going to ask what is the cause of the movement of the will when it turns from the immutable to the mutable good. That movement is certainly evil, although free will must be mubered among good things since without it no one can live aright. We cannot doubt that that movement of the will, that turning away from the Iord God, is sin; but surely we cannot say that God is the author of sin? God, then, will not be the cause of that movement; but what will be its cause? If you ask this, and I answer that I do not know, probably you will be saddened. And yet that would be a true answer. ${ }^{26}$

Augustine pleads ignorance concerning the cause of the actual turning of the will. Augustine is not throwing the question into the realm of mystery to avoid wrestling with it. Yaker points out two reasons "why Augustine's position ought not to be looked at as an abdication of the philosophical demand for intelligibility."127 one reason is that this is not the end to Auxustine's pursuit of truth in

\begin{tabular}{ll}
\hline 25 & Tbid., II, xix, 53. \\
26 & Ibid., II, 20x, 54. \\
27 & William Maker, "Mugustine on Evil: The Dilemma of \\
the Philosophers," The International Journal for \\
Philosophy of Religion Vol. 15 (1984) p. 155.
\end{tabular}


the area of the problem of evil. He is not just quitting.

The other reason is that the nature of the will itself is such that this question is unanswerable. "This is the fact that we experience the will as an initiating or undetermined causal force, as something which in and of itself causes things to happen which would otherwise not happen."128 It seems, for his account, that there can be no cause outside of the choosing agent himself.

All good is from God. Hence there is no natural existence which is not fram God. Now that movement of "aversion," which we admit is sin, is a defective movement; and all defect comes from nothing. observe where it belongs and you will have no doubt that it does not belong to God. Because that defective movement is voluntary, it is placed within our power. If you fear it, all you have to do is simply not to will it. If you do not will it, it will not exist. 29

Augustine closes Book II by setting up the question concerning the cause of the will's turning. This leads directly into the complicated question of the compatibility of divine foreknowledge and this concept of mman freedom. This he tackles in Book III.

De Iibero Arbitrio Book III

Book III opens with a discussion of the relationship between divine foreknowledge and human freedom. Evodius is still pressing his question concerning the origin of the will's turning, "[w] hence arises the movement by which the will itself turns from the unchangeable good, 
which is the common property of all, to its own interests....130 This is important to him because this question captures the issues regarding where the blame lies for the sinful will and all of the evil which resulted. He writes, "[I]f free will is so given that it has that movement by nature, it turns of necessity to mutable goods; and no blame attaches where nature and necessity prevail."131 In other words, if anything, such as God's foreknowledge which Evodius brings up presently, is such that the movement of the will from the immutable to the mutable good is necessary (in just such a way that the soul cannot avoid this movement), the person cannot be held responsible.

The type of freedom that is deemed necessary for moral culpability, here as in the writings surveyed in Chapter II, is an incompatibilist view. As I have indicated, I take this to mean that for a person to be sufficiently free regarding a choice, he must be actually able to choose either of the alternatives even if every other antecedent condition remained the same. Augustine writes:

Moreover, unless the movement of the will towards this or that object is voluntary and within our power, a man would not be praiseworthy when he turns to the higher objects nor blameworthy when he turns to lower objects, using his will like a hinge. ${ }^{32}$

The reference to a hinge in this passage is a comparison which highlights this feature of the will. Just as one can turn a hinge either way, one can turn one's will either towards the highest good or to some lower good. It is within one's power to choose either and so to Ibid., III, $i, 1$.

32 Ibid., III, i, 3. 
"do otherwise."

Evodius turns to the problem of divine foreknowledge:

I have a deep desire to know how it can be that cod knows all things beforehand and that, nevertheless, we do not sin by necessity....since cod foreknew that man would sin, that which cod foreknew must necessarily come to pass. How then is the will free when there is apparently this unavoidable necessity? ${ }^{33}$

Augustine articulates the problem as follows:

Your trouble is this. You wonder bow it can be that these two propositions are not contradictory and incompatible, namely that cod has foreknowledge of all future events, and that we sin voluntarily and not by necessity. For if, you say, God foreknows that a man will sin, he must necessarily sin. But if there is necessity there is no voluntary choice in sinning, but rather fixed and unavoidable necessity. You are afraid that by that reasoning the conclusion may be reached either that God's foreknowledge of all future events must be impiously denied, or, if that cannot be denied, that sin is committed not volumtarily but by necessity. 34

Augustine takes three approaches to this question. The first two highlight undesirable consequences which follow if God's foreknowledge did preclude freedom of the will. The third is an investigation into the necessity that attaches to knowledge.

Augustine's first approach in answering this problem is to point out that if God's foreknowledge rules out future miman freedom, it also rules out cod's own freedom. It is assumed that cod is free in any and all of His actions.

Don't you see that you will have to be careful lest scmeone say to you that, if all things of which cod has foreknowledge are done by necessity and not voluntarily, his own future acts will be done not 
voluntarily but by necessity. ${ }^{35}$

Augustine's second approach is to show that, if foreknowledge precluded freedom, it would be possible for God to make Evodius happy, against his will. If, for instance, it is true that in exactly one year, Evodius will be happy, then God knows that this is true. If cod's foreknowledge creates necessity, then Evodius will be happy by necessity. If Evodius is happy (in one year) by necessity and not voluntarily, then it is possible that he is made happy against his will. Augustine, here, is making use of the fact that, in his view, to say that something happened "by necessity" is equivalent to saying that it occurred "not voluntarily."

According to Evodius, this is impossible. Augustine concludes that, "Therefore though God knows how we are going to will in the future, it is not proved that we do not voluntarily will anything."36 He goes on:

When you said that you did not make yourself happy, you said it as if I had denied it. What I say is that when you become happy in the future it will not take place against your will but in accordance with your willing. Therefore, though God has foreknowledge of your happiness in the future, and though nothing can happen otherwise than as He has foreknown it (for that would mean that there is no foreknowledge) we are not thereby compelled to think that you will not be happy voluntarily. That would be absurd and far from true. God's foreknowledge, which is even today quite certain that you are to be happy at a future date, does not rob you of your will to happiness when you actually attain happiness. Similarly if ever in the future you have a culpable will, it will be none the less your will because God has foreknowledge of it. 37

$\begin{array}{ll}35 & \text { Ibid. } \\ 36 & \text { Ibid., III, iii, } 7 .\end{array}$


Cod foreknows both the voluntary willing and the result of that willing. In this way, His foreknowledge, rather than eliminating mman freedom, actually preserves and protects it.

Cod has foreknowledge of our will, so that of which he has foreknowledge must come to pass. In other words, we shall exxercise our wills in the future because he has foreknowledge that wo shall do so; and there can be no will or voluntary action unless it be in our power. Hence cod has also foreknowledge of our power to will. My power is not taken from me by God's foreknowledge. Indeed I shall be more certainly in possession of III power because he whose foreknowledge is never mistaken, foreknows that I shall have the porrer. 38

\section{As Craig observes:}

Hence, foreknowledge, far from being incompatible with free will, actually serves to guarantee it. For since cod foreknows our future acts of will, these will come to pass as He foreknows them. He foreknows that these acts will be acts of our will and therefore within our power.... [Alugustine] argues that even if there is in cod's mind a definite pattern of causation which he foreknows, it does not follow that no room is left for the free choice of our will. For our wills are included in that very pattern of causes foreknown by cod, since the wills of men are included among the causes of men's deeds. How then can the order of causes which is fixed in cod's foreknowledge deprive us of the use of our will when our wills are an important part of the causal series itself? our acts of will have just as much power as cod foresaw them to have. 39

The third approach Augustine makes to the foreknowledge/free will

issue is an analysis of the necessity that attaches to foreknowledge.

Augustine asks Evodius whether his view that foreknowledge is

incompatible with muman freedom is due to the fact that it is cod's

foreknowledge that is being considered or is it cue to the nature of

38 Ibid., III, iii, 8.

39 Filliam Lane Craig. Foreknowledge and Future Contingents from Aristotle

to suarez (Leiden: E. J. Brill, 1988), Pp. 68-69. 
foreknowledge in general. Although Evodius claims that it is divine foreknowledge that is the problem, Augustine demonstrates that any sort of foreknowledge will bring the problem Evodius sees.

If you knew in advance that such and such a man would sin, there would be no necessity for him to sin. [Evodius replies]-Indeed there would, for I should have no real foreknowledge unless I knew for certain what was going to happen. [Augustine's conclusion]-80 it is foreknowledge generally and not God's foreknowledge specially that causes the events foreknown to happen by necessity? There would be no such thing as foreknowledge unless there was certain foreknowledge. 40

Auxgustine's point is that the problem Evodius has raised is not unique to divine foreknowledge. It is true of any possible foreknowledge. Inplied in this is the view that knowledge entails true belief. If what one claims to know is false, one does not have knowledge. Only what is true can be known. Therefore, if one knows ' $p$ ', ' $p$ ' must be true. Hence, if one foreknows that ' $\mathbf{x}$ ' will occur, it is certain that ' $\mathbf{x}$ ' will occur. If anyone, not just God, has foreknowledge that a man will sin, it is certain that the man will sin. Auxgustine describes this case.

Unless I am mistaken, you would not directly conpel the man to sin, though you knew beforehand that he was going to sin. Nor does your prescience itself compel him to sin even though he was certainly going to sin, as we must assume if you have real prescience. 80 there is no contradiction here. simply you know beforehand what another is going to do with his own will. similarly God compels no man to sin, though he sees beforehand those who are going to sin by their own will. 41 
If it is foreknowledge simply that seems to preclude free will, this is because any foreknowledge of an event carries with it the certainty that the event will take place. The necessity attaches to the foreknowledge as a type of knowledge. It does not attach to the foreknowledge because of the divine nature of the knowledge. Foreknowledge of an action, whether by cod or any other knowing being, does not compel the action. The certainty of knowledge does not entail the necessity of the object of knowledge.

This distinction has came to be known as the distinction between the necessity of the consequence and the necessity of the consequent. As Konyndyk explains:

Basically, the distinction is between two different ways of taking the scope of necessity in a conditional. The occurrence of the word "necessarily" in a conditional may signal the necessity of the connection between the antecedent and the consequent of that conditional, that is to say, the necessity of the consequence. Or "necessarily" may indicate the necessity of the consequent of the conditional. 42

Using 'N' as 'necessarily', we can represent this distinction as:

$x$ (if $p$, then $q)=$ the necessity of the consequence.

(if $\mathrm{p}$, then $\mathrm{kq}$ ) = the necessity of the consequent.

A proper understanding of foreknowledge would reveal that the necessity of the consequence applies but the necessity of the 42 Renneth Konyndyk, Introductory Modal Iogic (Notre Dame, Ind.: University of Notre Dame Press, 1986), p. 21. 
consequent does not. Only if, hoverer, the necessity of the consequent applied, would the event itself be necessary and the freedom of indifference concerning the event be eliminated. In this respect, Augustine points out, foreknowledge is similar to memory knowledge.

Just as you apply no compulsion to past events by having them in your memory, so cod by his foreknowledge does not use compulsion in the case of future events. Just as you remember your past actions, though all that you remember were not actions of your own, so cod has foreknowledge of all his own actions, but is not the agent of all that he foreknows. ${ }^{43}$

Augustine concludes that God is not the cause of the movement of the will of a mman being even though God foreknows that the person's will will so move. The person himself is the agent and cause of his own will's turning. In this way, God is not to be blamed for the evil will. Each person is culpable for his or her own turning of will from the highest good to some lesser goods.

It is important to observe what it is that Augustine is attempting to demonstrate. He is not arguing for a reconciliation of divine foreknowledge and muman freedom in which divine foreknowledge produces a causal necessity and yet the will is still free. Rather, he is arguing that divine foreknowledge, even though it is never mistaken, does not cause the will to choose one way or another. The will is free from causal necessity in the sense that craig observes: "Rather, we have seen that in books one, two, and three Augustine appeared to affirm a view of the will which entailed the liberty of De lib arb., III, iv, 11. 
indifference. 144

Augustine, in a brief section, nest argues from the notion of obligation to the fact of mman freedom. He wxites, "No man is guilty because be has not received this or that power. But because he does not do as he ought he is justly held guilty. Obligation arises if be has received free will and sufficient power.115 since obligation seems to be a fact of moral experience, it is reasonable to believe that people have been given free will and sufficient power to do what is right. Guilt comes to the individual only if the individual fails to choose that which the individual could choose. There is no real guilt in the absence of real freedom of will.

Another way to approach this is to suppose that there were no free will. Augustine writes, "If 'oughtness' depends upon what has been given, and man has been made that he sins by necessity, then he ought to sin."46 If, then, man is not sufficiently free to choose good over evil, man would be right to sin. All sin would come from his nature. Perhaps God could be blamed but not man because man "ought" to sin. Augustine is appealing to an intuition that it seens unacceptable to say that one ought to sin. If one rejects that one ought to sin, Augustine wants to say that one must acknowledge that sin is by choice.

Evodius appears again in the dialogue at this point and moves the discussion on to another issue.

\footnotetext{
44 William Lane Craig, The Problem of Divine Foreknowledge and Future contingents from Aristotle

45 to suarez, p. 71.

46 De lib arb., III, xV, 45. Ibid., III, xv, 46.
} 
But I should like to know, if possible, why those beings do not sin whom God knew beforehand would not sin, and why those others do sin whom he foresaw would sin. I do not now think that God's foreknowledge compels the one to sin and the other not to sin. But if there were no caluse rational creatures would not be divided into classes as they are: those who never sin, those who contimually sin, and the intermediary class of those who scmetimes sin and scmetimes are turned towards well-doing. What is the reason for this division? I do not want you to reply that it is the will that does it. What I want to know is what cause lies behind willing? ${ }^{47}$

It may be the case, Augustine points out, that Evodius is asking for an infinite regress of causes. Using the idea suggested by the scriptural phrase, "Avarice is the root of all evils" (I Tim 6:10) Augustine presses Evodius' question.

But you ask what is the cause of this root. How then will it be the root of all evils? If it has a cause, that cause will be the root of evil. And if you find a cause, as I said, you will ask for a cause of that cause, and there will be no limit to your inquiry. ${ }^{48}$

But what cause of willing can there be prior to willing? Either it is a will, in which case we have not got beyond the root of evil will. Or it is not a will, and in that case there is no sin in it. Either, then, will itself is the first cause of sin, or the first cause is without sin. ${ }^{49}$

Augustine is here arguing that the evil will is its own cause. There is no prior cause which makes the will choose evil. If anything forces the will to choose sin, it is not a voluntary choice and, therefore, it is not sin. This view of the cause of the evil will is a case of agent causation. The person himself is an uncaused cause with respect to the choice. He is not compelled either way and he becomes the cause of the choice when he chooses.

$\begin{array}{ll}47 & \text { Tbid., III, xvii, } 47 . \\ 49 & \text { Ibid., III, xvii, } 48 .\end{array}$


Robert Brown argues at length that this first evil will must be incomprehensible:

\begin{abstract}
Here he asserts that an evil will has no efficient cause, or no "essential" cause. The evil vill stands as efficient cause of an evil deed, but this will itself has no efficient cause. If the first instance of evil willing did have an efficient cause, that cause could only be the nature of the willing being itself. (Excluded from the outset are the other two possibilities: it has a prior evil will as its cause; cod himself causes the evil will.) If the first being that willed evil had a created nature that was good, its willing evil is an inexplicable fact which cannot be accounted for by its nature. 50
\end{abstract}

Brown's main concern in his paper is with passages in which Augustine tries to make this first evil will explicable. According to Brown, Augustine's admission of ignorance in this passage is one of his "better moments". 51 Brown himself will not ultimately accept agent causation. Rather, he looks either to a necessary fall, as in Irenaeus, or a "transcendental fall", as in Kant. Augustine, however, is here asserting that the first evil will is inocmprehensible simply because the muman soul is the agent and cause of the will. There is no further explanation. 52

Augustine then discusses some scriptural passages which seem to indicate that it is outside the soope of a mman being's power to choose good. This leads to a discussion about the results of the fall 50 Robert F. Brown, "The First Evil will vust be Incomprehensible: A Critique of Augustine," Journal of the American Academy of Religion Vol. 46 p. 319.

Ibid., p. 326. For a contemporary defense of a similiar position, see Roderick Chisolm's paper, "Human Freedom and the self' in Free Will Gary Watson ed. (Oxford: axford University Press, 1982), pp. 24-35. 
of man.

If this were a description of man's nature and not of the penalty of sin, his situation would not be sinful. If man has not departed from the natural state in which be was created, and which could not be made better, be is doing what he ought even if be does evil. But now man might be good if he were different. Because he is what he now is, he is not good, nor is it in his powar to become good, either because be does not see what be ought to be, or, seeing it, has not the porer to be what he sees be ought to be. Who can doubt that his is a penal state?

The penal state is that man has lost that of which be was umilling to make good use. "In fact there are for every sinful soul these two penal conditions, ignorance and difficulty."54 Each sinful man has lost the ability to know what is right, completely, and he has also lost the ability to perform that which is right, completely, even if he should choose to try to perform it. Of this ignorance and difficulty Augustine writes, "these do not belong to the nature of man as he was created. They are the penalty of man as condermed. When we speak of the freedom of the will to do right, we are speaking of the freedom wherein man was created. 155

Augustine, in this discussion of the difficulty of right choosing, does not appeal to habit, as he did in Acta contra Fortumatum Manichaeum. Instead he implies that the effects of Adam's sin go deeper than merely an inherited disposition to form habits of the soul which include strong inclinations to choose one way rather than another. Man, after sin, is no longer in his natural state. Of man Augustine writes that "he is not good, nor is it in his power to beccme good." In other 
words, to scme degree, man's original nature has been lost because of Adam's sin.

Originally, Adam was free to choose to live rightly or to live wrongly. There was no compulsion either way. Once he sinned, Adam lost the ability to live rightly in his own strength. His original nature was corrupted and he lacked the discermment to understand what was right as well as the power to do what small part of the right he could recognize.

This is a stronger view of the hinderance of the will which results from sin than that which we abserved in De libero arbitrio Book I. This is still not Augustine's most developed position on this. Here, he insists that guilt is not inherited as a result of Adam's sin. He also bolds that it is still within the power of the individual to turn to God in order to receive divine aid to overcome this penalty of sin. The turning to God is possible without the prior intervention of His grace. As we shall see in the next chapter, after his becoming bishop, Augustine changed on both of these points. Guilt was seen as inherited and even the turning to cod to receive help was impossible without cod's prior grace.

Augustine, once be distinguished between the freedom with which mumanity was created from the freedom with which it now finds itself, seeks to defend the doctrine of the inherited penalty of sin. some, he admits, object to this.

They say: If Adam and Eve sinned, what have we miserable creatures done to deserve to be born in the darkness of ignorance and in the toils of difficulty, that, in the first place, we should err not lnowing what we ought to do, and, in the second place, when the precepts of justice begin to be cpened out to us, we should wish to 
obey them but by some necessity of carnal lust should not have the power? ${ }^{56}$

Augustine's first response is a rather abusive ad hominem, "Reep quiet and stop mumuring against God."157 secondly, and more to the point, he appeals to the fact that each person sins even in relation to the capacity with which he or she was born.

You are not held guilty because you are ignorant in spite of yourself, but because you neglect to seek the knowledge you do not possess. You are not held guilty because you do not use your wounded members but because you despise him who is willing to heal them. These are your own personal sins. ${ }^{58}$

It is not the sin which one involuntarily inherits that is the source of guilt and punishment, but, Augustine is arguing, it is the personal sin of the individual which merits guilt and pumishment. These personal sins are voluntary and not due to Adam at all. Even if one's capacity to understand or choose right is impaired by the inherited penal effects of Adam's sin, one still voluntarily sins when one chooses to ignore the capacity one has been given and deliberately lives below one's possibilities.

Even though muman freedom is, to same degree, lost in the Fall, it is still true, according to Augustine, that Adam's descendents have the ability to turn and receive divine aid for overcoming this loss. This is a foreshadowing of the great emphasis which will be placed on the necessity of God's grace in same of Augustine's subsequent works. He

$\begin{array}{ll}56 & \text { Tbid., III, xix, } 53 . \\ 58 & \text { Ibid. }\end{array}$


writes:

But if any of Adam's race should be willing to turn to God, and so overcome the punishment which had been merited by the original turning away from cod, it was fitting not only that he should not be hindered but that he should also receive divine aid. In this way also the creator showed how easily man might have retained, if he had so willed, the nature with which he was created, because his offspring had power to transcend that in which he was born. 59

It is important to observe that in this passage, Augustine implies that the divine aid comes after a person is willing to turn to cod. While it is true that we need divine aid to overcome that punishment of ignorance and difficulty, it seems that this divine aid comes to those who are willing to turn to God. Augustine does not say, at this point, that cod gives aid in order to enable some to be willing to turn to God. Rather, being or becoming willing to turn, seems to be prior to cod's intervention.

Even though man inherits ignorance and difficulty as a result of Adam's sin, man has been given great advantages, even after the fall. It is possible for the individual soul to advance "towards knowledge and tranquility until it reaches the perfection of the happy life."60 since this advance is possible, after the fall, it is just to hold as culpable those who choose not to advance.

If by its ow will it neglects to advance by means of good studies and piety- for the capacity to do so is not denied to it- it justly falls into a still graver state of igmorance and struggle, which is now penal, and is ranked among inferior creatures according to the appropriate and fitting goverment of the universe. Natural ignorance and natural impotence are not reckoned to the soul as guilt. The guilt arises because it does not eagerly pursue 
knowledge, and does not give adequate attention to acquiring facility in doing right. ${ }^{61}$

It is the individual's own umillingmess to use the abilities which he has been given and to purposefully grow towards wisdom that brings guilt. Again, Augustine is denying that the guilt of Adam's sin is inherited. Only the penalty is passed on.

\section{Assessment}

Throughout this period, Augustine acknowledges, more explicitly than previously, the reality of moral struggle. Concerns about the nature of this struggle and its relevance to the freedom of the will take up a central place in these writings.

In Acta contra Fortumatum Manichaeum, the will is pictured as freely choosing scme option which may result in an experience of pleasure. The attraction of this pleasure may entice the will to form a habit of choosing in such a way that the pleasure is repeated. This habit can become so strong that the will may be unable to conquer it. Before this habit is formed, the will is free to choose or refuse the option. It is only after choice is made that the pleasure produces the habit which may become binding on the will. It is the disposition to form habits in this way that is inherited from Adam. Guilt and moral difficulty are not mentioned as being directly inherited.

In De libero arbitrio III, Augustine is holding that the nature of Adam himself was corrupted when he sinned. This corruption resulted in $\overline{61}$ Ibid. 
the inability to choose rightly, in a consistent manner, or to accomplish that little bit which is rightly chosen. This corrupt nature is inherited by all of the descendants of Adam. As a result, Augustine introduced the distinction between the freedam of the will with which Adam was created and that which all subsequent generations experience. Adam had a total freedom of indifference. He could choose to be good or evil. Each of his descendents have a limited freedam of indifference. The choice is available to be evil or to turn for divine aid in order to be good. Whether the person turns for this help or not is within the power of the person's will. This is so even if it is not in the power of a person's will to live rightly independently of divine aid.

In both of these works Augustine seems to be shifting his position on the freedom of the will towards a compatibilist one. Certainly, there is a recognition that outside factors have a great influence on the ability of the will to choose rightly. A careful comparison of the texts will reveal, however, that he still holds that "necessary" and "voluntary" are of contrary meaning. Augustine still holds the incompatibilist position in that the voluntary nature of the choice implies that the will could have chosen each of the two options without a change in antecedent conditions.

This becomes clear when it is remembered that, in the discussion of divine foreknowledge and hman freedom, Augustine was attempting to show "how it can be possible that these two propositions are not contradictory and incompatible, namely that cod has foreknowledge of all future events, and that we sin voluntarily and not by 
necessity."162 Craig's analysis of this is helpful:

On the compatibilist view, Augustine has to reject the second as false, for we do indeed sin voluntarily and by necessity. But the whole intention of Augustine is to show that both propositions are true. ${ }^{63}$

Augustine's assertion is that we sin voluntarily and not by necessity. In his view, these are clearly contrary to one another. The fact that he takes so many pages to demonstrate that divine foreknowledge does not introduce the kind of necessity which eliminates the voluntary nature of a sinful choice is all the more support for the claim that he is holding the incompatibilist position.

In Acta contra Fortunatum Nanichaeum, Augustine argues that there is no sin where there is compulsion. He writes, "he who is compelled by nature to do anything, does not sin. But he who sins, sins by free will."64 In this same passage, he equates a person's sinning by free will with sinning "of his own will" and also with sinning voluntarily. These are contrasted with being compelled by nature. If it is our nature that produces sin, it is not our will and the sin is not voluntary, it is necessary. Even when the moral agent is bound by habit, the person became bound voluntarily and can turn voluntarily to receive the divine aid and be freed.

Ibid., III, iii, 6.
63 Filliam Iane Craig, The Problem of Divine
Foreknowledge and Future contingents fram Aristotle
to Suarez, p. 71.
C Fort., 17.




\section{Summary}

During this period, from his ordination to the priesthood to his advancement to the rank of bishop, Augustine's view of the freedom of the will was in transition. There are four observations to be made. First, it is still considered part of the essential nature of sin that it be voluntary. This is understood as being in contrast with compulsion or necessity. Unless the will could have chosen either option, it is not a voluntary choice.

The second observation is that sin is still located in the disordered will which chooses to prefer a lower good to the highest good. The object which the soul prefers is not, in itself, evil. Third, Augustine takes a deeper and more realistic look at the moral struggle. He acknowledges that out of certain choices of the will habits of choice can arise which are difficult or impossible to overcome. Even within this period, his view of the depth of the difficulty inherited from Adam increased.

The fourth observation is that divine aid is necessary in order for the will to overcome its difficulties and turn to cod. It seems that Augustine holds that it is within the power of the soul to be willing to turn to God even if the actual turning can only be accomplished with divine aid. This aid comes to those who choose to be willing to turn to cod. In this way if the individual chooses to be willing to turn to cod, he or she will be able to turn. The ability to turn, however, is from cod. 
We shall see in the next chapter that Augustine will hold that even the willingness to turn to God is a gift from God. It is not within the soul's power to be willing unless cod intervenes to enable the soul to be willing. 
CEAPIER IV

\begin{abstract}
AUGUSTINE'S VIEN OF THE FREFDOM OF THE WIIL IN THE EARLY YEARS OF HIS EPISOOPACY
\end{abstract}

It was shortly before Christmas in 395, when valerius elevated Augustine from the rank of priest to that of coadjutor-bishop. Augustine had already been using his extraordinary gifts to handle mach of the burden of the administration of the cmurch. Within a year of this promotion, Valerius had died and Augustine became the ruling bishop in Hippo. He served in this capacity for the remainder of his 1ife.

As we noted earlier, ${ }^{1}$ the church in Hippo was surrounded by controversies with Manichaeans and Donatists. Meeting the challenge of these sects with sermons, debates and other works occupied much of Augustine's attention. In addition, he delivered many exegetical sermons and wrote on exegetical problems. Of special significance is De diversis quaestionibus ad simplicianum which Augustine sent to the bishop simplician in response to questions concerning several difficult portions of scripture.

1 see p. 46, above. 
In these early years as bishop, Augustine also wrote what has become his most widely read work, the Confessiones. He began in 397 and completed it by $401 .^{2}$ This work can be considered an autobiography of the heart. Augustine is less concerned with events and achievements than he is with the development of his interior life. The constant theme of his confessing is his heart and how his motivations shaped his thought and life.

The confessiones is a rich mine from which much can be quarried regarding Augustine's life, thought and concerns. I shall concentrate my study of this period on Augustine's view of the freedom of the will. From both the Confessiones and De diversis quaestionibus ad Eimplicianum we shall see a position on the freedom of the will which represents significant developments from his earlier views. These two works are, in some sense, complimentary to one another. As Petar Brown observes:

surprisingly enough, therefore, the austere answer to the second Problem of the Various Problems for simplicianus is the intellectual charter of the confessions. For both books faced squarely the central problem of the nature of muman motivation. In both books, the will is now seen as dependent on a capacity for "delight", and conscious actions as the result of a mysterious alliance of intellect and feeling: they are merely the final outgrowth of hidden processes, the processes by which the "heart" is "stirred", is "massaged and set" by the hand of cod." 
Augustine's view of the Freedom of the will in

De Diversis Quaestionibus Ad simpliciamum

Simplician was the man who succeeded Ambrose as bishop in vilan in 397.4 He had made Augustine's acquaintance before the latter's conversion in 386. Simplician had influenced Augustine greatly by both encouraging him to read the Platonists and by telling him of the conversion of Victorimus (the translator of the Platonist writings which Augustine was reading). ${ }^{5}$ over the years the two maintained contact. Simplician had read Augustine's Expositio quarumdam propositionum ex Epistola ad Romanos and requested further help in understanding some of st. Paul's difficult texts. Augustine was only too pleased to try to solve the perplexities and sent De diversis quaestionibus ad simplicianum with a cover letter, probably in 397. In this letter he mubly states:

As for the questions which you have condescended to command me to resolve, even if through the dullness of my mind I did not understand them, I might through the assistance of your merits find an answer to them. This only I ask, that on account of IIy weakness you intercede with God for me, and that whatever writings of mine come into your sacred hands, whether on the topics to which you have in a manner so kind and fatherly directed my attention, or on any others, you will not only take pains to read them, but also accept the charge of reviewing and correcting them; for I acknowledge the mistakes which I myself have made, as readily as the gifts which God has bestowed on me. ${ }^{6}$

\footnotetext{
4 see the Introduction to To simplician - on Various Questions in Augustine: Earlier Nritings ed. J. H. 8. Burleigh (Philadelphia: Westminster Press, 1953), p. 372. All citations of To simplician 5 (hereafter Ad simp.) are to this translation. 6 See Conf., VIII, 2. Ep., 37, 3.
} 
Book I consists of Augustine's treatment of two questions. The first is concerning the text of Romans 7:7-25. The second is on Romans 9:10-29. It is Augustine's exposition of this second question which is so vital in seeing the development of his views. This is the same passage on which he wrote just two years earlier in question 68 of De diversis quaestionibus IXXXIII. 7 Iooking back over his treatment of this second question same thirty years later, Augustine writes, "In the solution of this question, I, indeed, labored in defense of the free choice of the mman will; but the grace of cod conquered.... "18 It is in this section that Augustine elaborates a view of the efficacy of human choice which is, according to some commentators, his mature view. 9

Augustine looks into this section of scripture by first consulting the context. He wishes to understand this particular passage in light of the author's purpose for the whole book. Of this purpose, Augustine writes:

It is that no man should glory in meritorious works, in which the Israelites dared to glory, alleging that they had served the law that had been given to them, and that for that reason they had received evangelical grace as due to their merits. Bo they were unwilling that the same grace should be given to the centiles, as if they are unworthy of it unless they undertook to observe the Jewish sacred rites. 10

For the date of 394-395 for the questions on st. Paul, in De diversis quaestionibus IXxxII comes from David Mosher's Introduction to his translation

9 Retr., II, 27. See Poralie, pp. 182-184 and Gilson, Pp. 159,160 and Vernon Bourke, Auqustine's quest of Wisdom (Milwaukee: The Bruce Publishing Company, 1945), p. 146. Ad Simp., I, Q. 2, 2 . 
Paul's purpose in the book of Romans, then, is to demonstrate that no person can boast in his or her own works as if they can win God's approval. This sheds light on Paul's meaning in the passage at hand. Grace and meritorious works cannot coexist. They are opposites. Augustine writes, "The Jews did not understand that evangelical grace, just because of its very nature, is not given as a due reward for good works. Otherwise grace is not grace." 11

Augustine's concern is not to eliminate or to belittle good works. He wishes to emphasize the nature of grace. specifically, that grace, by definition, precedes works. "No man is to think that he has received grace because he has done good works. Rather, he had not done good works unless he had received grace through faith."12 It takes a gracious work of cod in order for an individual to perform anything that is good. Augustine writes, "And good works, if there are any, follow and do not precede that grace, as has been said."13

Augustine claims that, in the passage from Romans 9, we have been given proof that grace does precede works. This is the point of Paul's explanation of the election of Jacob over Esau. Before these twins were even born, God chose the younger, Jacob, to be heir of the promises of God. It would be Jacob's line, rather than Esau's which would bring forth the Messiah of Israel. It is an important fact that this choice of God happened before either Jacob or Esau were born. Augustine cites the saripture, "'For the children being not yet born and having done nothing either good or evil, not of works but of him that calleth, it 11 
was said unto her, the elder shall serve the younger."' 14 since the choice occurred before birth, neither Jacob nor Esau could have merited God's selection by their good works. Augustine writes of this text, "Grace is therefore of him who calls, and the consequent good works are of him who receives grace. Good works do not produce grace but are produced by grace."15

Auguatine then investigates the meaning of the verse, "That the purpose of God according to election might stand." (Romans 9:11) He raises several questions about this verse. First, "How can election be just, indeed, bow can there be any kind of election, where there is no difference?"16 If there is, as yet, no difference in works or in faith or in merit between Jacob and Esau, what is there to distinguish between them, so that God should choose the one and not the other? There is nothing.

Augustine next asks, "But how could there be election, or what kind of election could there be, if there was no distinction of merits because they were not yet born and had done nothing?"17 Perhaps, he reasons, election is based upon some distinction in their natures. He rejects this, after considering it, because of the fact that Jacob and Esau were twins. As a result, there was no difference in the circumstances surrounding their conception or birth that could have produced some difference in their natures. Augustine especially points out that the case of twins is an important counter example to the claims of astrology.

\begin{tabular}{ll}
\hline 14 & Trid., I, Q. 2, 3. Augustine is quoting Romans \\
15 & $9: 11,12$. \\
16 & Trid. \\
17 & Trid., I, Q. 2, 4.
\end{tabular}


Augustine next considers whether or not God's election of Jacob and rejection of Esau could have been based on His foreknowledge of Jacob's future faith and Esau's future lack of faith. "could it be 'according to election' because cod has foreknowledge of all things, and foresaw the faith that was to be in Jacob even before he was born?"18 Augustine rejects this also. His argument is that there is little difference, if any, between cod foreknowing Jacob's faith and foreknowing his works. Neither Jacob's faith nor his good works had been in existence when Jacob was chosen to Iule over Esau. If Paul, in this text, is arguing that election cannot be based on works simply because election preceded the lives, and therefore, the works of those involved, he cannot at the same time hold that election was based on Cod's foreknowledge of Jacob's faith which was equally non-existent at the time of Jacob's election. Just as Jacob had done nothing either good or evil prior to birth, he could not have believed anything before cod had chosen him.

It is significant that Augustine rejects the view that election is based on foreknowledge, because this is the very view he expounded on this verse in his Expositio quarundam propositiomum ex Epistola ad Romanos and his De diversis quaestionibus IXXXIII in 394-395. However, at the present time, Augustine writes:

The apostle, therefore, did not want us to understand that it was because of God's foreknowledge that the younger was elected to be served by the elder..... It was not of works, because being not yet born they had done no works. But neither was it of faith, because they had not faith either. What, then, was the reason for it? ${ }^{19}$ 
Augustine turns again to the text but with a slightly different reading in order to try to shed light on its meaning. "Possibly we are to make a distinction here. Perhaps we should connect the words, 'That the purpose of Cod according to election might stand, 'with what precedes rather than with what follows.0120 In this case the sentence should not be read as, "The elder shall serve the younger in order that cod's purpose according to election might stand." This is the reading that implies that there is something in the younger that merited his selection over the elder. Rather the sentence should be read as, "When they were not yet born and had cone neither good nor evil, that the purpose of God according to election might stand..." Augustine writes that this means:

There could be no election on account of good works, according to which the purpose of cod might stand. so inot of works but of him that calleth," that is, of cod who justifies the ungodly by grace calling him to faith, "it was said to her, the elder shall serve the younger." so that the purpose of cod does not stand according to election, but election is the result of the purpose of cod.21

The fact that the elder was going to serve the younger was decided by cod before either was born and had cone anything either good or evil. It is this prior choice of God, which is not acoording to anything but cod's om call, that is so in order that "the purpose of cod according to election might stand." cod's purpose according to election is for him to call individuals purely by his own free choice and undeserved favor without regard to their merit or faith. This

$\begin{array}{ll}20 & \text { Ibid., I, Q. 2, } 6 .\end{array}$


completely rules out any boasting. "But bere, when be says, 'llot of works but of him that calleth,' be wants us to understand that it is not by election through merits, but by the free gift of cod, so that no man may exult in his good works.1022

In light of the fact that election is based purely upon God's own choice, Augustine asks, "whether faith merits a man's justification, whether the merits of faith do not precede the mercy of God; or whether, in fact, faith itself is to be mubered among the gifts of grace. $1{ }^{23}$ He quickly concludes that faith itself is a gift of grace. "Onless, therefore, the mercy of cod in calling precedes, no one can even believe, and so begin to be justified and to receive power to do good works. So grace comes before all merits."124 Augustine's conclusion concerning Jacob's election, then, is that it was entirely of God who called Jacob and not in any way of Jacob/s works or faith. Augustine next turns his attention to the rejection of Esau. He asks, "How could he have merited this by evil deeds of his own doing, since these things were spoken before he was born, and before he had done aught of good or evil?1125 Esau's rejection could not have been because cod had foreknown his evil deeds or his lack of faith. Otherwise, Augustine notes, "he must also have predestined Jacob to be served by his elder brother because he foreknew his future good works. $11^{26}$

Augustine asks, then, "[H] ow did Esau deserve to be hated before

Ibid.

Ibid., I, Q. 2, 7 . Ibid.

Ibid., I, Q. 2, 8. Ibid. 
he was born?!127 It seems inconceivable that God would make anything that He would hate but it has been shown that Esau did not merit either hatred or love. There must be same other answer. Augustine notes that Pawl, in the passage of scripture, anticipates these kinds of questions by asking "What shall we say, then? Is there unrighteousness with God? God forbid...For he saith to soses, I will have mercy on whom I will have mercy, and I will show compassion on whom I will have compassion." (Romans 9:15) Augustine comments on this, "If God will have mercy on whom he will have mercy and show compassion to whom he will show compassion, our chief difficulty remains, which is, why did his mercy fail in Esau's case? ${ }^{28}$

The mercy of cod is so complete as to produce faith sufficient for justification in whomever it is on whom God bestows it. Augustine writes:

If amyone boasts that he has merited compassion by his faith, let him know that God gave him faith. God shows compassion by inspiring faith in one on whom he had compassion in giving to one who was still an unbeliever a share in his calling.

The question remains as to why Esau did not receive the mercy that would have produced the faith and good works in him. Augustine considers whether or not the answer could be that Esau was unvilling to receive it. If, however, Esau did not receive God's mercy because he was umilling, Jacob must have received mercy because he was willing. In this case, faith would not be a gift of God but a reward for right

\begin{tabular}{ll}
\hline 27 & Ibid. \\
28 & Irid., I, Q. 2, 9. \\
29 & Ibid.
\end{tabular}


willingness. Perhaps, Augustine considers, the willingness to receive mercy is also a gift fram God.

Or can no one believe unless be wills, or will unless be is called, and can no one be called unless God by calling him also gives him faith? For no one can believe yoless be is called, although none can believe against his will. ${ }^{30}$

It must be observed that a person's believing, Augustine here implies, is never against the person's will. It is always in accordance with the will. This is important in that Augustine will insist that the person is free in his or her believing even though God gives the will to believe. As we shall see, he is beginning to use "free" and "voluntary" in a sense which does not necessarily imply the freedam of indifference.

If willingness to receive God's mercy is itself part of God's mercy, the question still stands as to why Esau was not given this mercy. He was rejected and yet, it seems, cod could have given him the mercy necessary to be willing to receive and to have faith.

But Esau was not yet born and consequently could be neither willing nor unwilling in all these matters. Why was he rejected while he was still in the womb? We come back to that difficulty, troubled not only by the obscurity of the question but also by our own abundant repetition. ${ }^{31}$

Augustine looks at the sentence, "Therefore it is not of him that willeth, nor of him that runneth, but of God that hath mercy" (Romans 9:16) and he relates it to Philippians 2:12,13 where Paul writes, Work Ibid. 
out your own salvation with fear and trembling; for it is cod which worketh in you both to will and to do his good pleasure." Of these Augustine writes, "There he clearly shows that the good will itself is wrought in us by the working of cod."32 He explains:

clearly it is vain for us to will unless God have mercy. But I do not know bow it could be said that it is vain for cod to have mercy unless we willingly consent. If cod has mercy, we also will, for the power to will is given with the mercy itself. It is cod that worketh in us both to will and to do of his good pleasure. If we ask whether a good will is a gift of cod, I should be surprised if anyone would venture to deny that. But because the good will does not precede the calling, but calling precedes the good will, the fact that we have a good will is rightly attributed to cod who calls us, and the fact that we are called cannot be attributed to ourselves. 8o the sentence, "It is not of him that willeth, nor of him that rumneth, but of God that hath mercy' cannot be taken to mean simply that we cannot attain what we wish without the aid of cod, but rather that without his calling we cannot even will. $33^{3}$

The act of willing is itself, then, a result of the mercy of cod. The ability of a person to will is dependent upon cod's gift of mercy to that individual. The efficacy of cod's gift of mercy to an indivicual is in no way dependent upon that individual's willingness to receive it or to will it. This is because the willing itself, any good willing, is included in the gift of mercy. God's choice of an indivicual precedes and is necessary and sufficient for that individual's good will. This dependence of a person's will upon cod, Augustine claims, is not merely a dependence upon cod in order to have the power to accomplish what is willed. It is a dependence for the very will itself. It is impossible to will rightly without cod's mercy and calling. 
This is a very different view of the will's dependence upon cod than Augustine defended in De libero arbitrio III. 34 There we saw that the will to turn to God seems to be within the power of the individual prior to cod's intervention. The view, here, that the will to turn to cod is not in the power of the individual without cod's intervention is what we have called the compatibilist view of the freedom of the will.

Augustine introduces a distinction between an effectual call of cod and a non-effectual call. This is to take into consideration the text in Natthew 20:16 in which it is written, "Wany are called but few are chosen." If there is no distinction between calls, then it is in the power of scme individuals, if not all, to choose whether or not they will respond to God's call. If this were the case, Augustine writes, "it could be said correctly that it is not of cod who hath mercy, but of the man who willeth and rumneth, for the marcy of him that calleth is not sufficient unless the obedience of him who is called follows."135 since this view has already been rejected, Augustine concludes that there must be two types of calling.

Many, that is to say, are called in one way, but all are not affected in the same way; and those only follow the calling who are found fit to receive it.... For cod calls in the way that is suited to those who follow his calling. The call comes also to others; but because it is such that they cannot be moved by it and are not fitted to receive it, they can be said to be called but not chosen. and again it would not be true that it is not of God who hath mercy but of man who willeth and runneth. For the effectiveness of God's mercy cannot be in the power of man to frustrate, if he will have none of it. If God wills to have mercy on men, he can call them in a way that is suited to them, so that they will be moved to 
understand and to follow. 36

God's mercy, then, is not extended to all who are called. It is extended only to those who are chosen. In this way it can be true that "God has mercy on no man in vain."17 Augustine contimues:

Those are chosen who are effectually called. Those who are not effectually called and do not obey their calling are not chosen, for although they were called they did not follow.....For, although he calls many, he has mercy on those whom he calls in a way suited to them so that they may follow. But it is false to say that "it is not of God who hath mercy but of man who willeth and runneth," because God has mercy. on no man in vain. He calls the man on whom he has mercy in the way he knows will suit him, so that he will not refuse the call. 38

This distinction between an effectual and a non-effectual call raises several important issues and is the basis upon which mman freedom is preserved in light of what seems to be the irresistible mercy of God. I shall make several abservations. First, it is to be remembered that cod's call is not based upon a foreknowledge of the individual's response. This, as we have seen, holds cod's call hostage to the will of man. God does, however, know how an individual would respond if a certain call is given, and, presumably, how he would respond if a different call is given.

second, it seems that this knowledge is the means by which cod chooses which type of call to send to individuals. He knows what would constitute an effectual call and what would constitute a non-effectual call for every individual. He bestows an effectual call on those on

\begin{tabular}{ll}
\hline 36 & Ibid. \\
37 & Ibid. \\
38 & Ibid.
\end{tabular}


whom He chooses to have mercy and He bestows a non-effectual call on those on whom He chooses to withhold mercy.

Thira, it is by a voluntary choice of the will, that an individual responds to God's effectual call. Trice in the cited passage Augustine emphasizes this. God calls the chosen individual "in a way suited to them so that they may follow." Again, Augustine writes, "he calls the man on whom he has mercy in a way he knows will suit him, so that he will not refuse the call." God's call does not overcome the will of the man. He calls those whom He chooses in conjunction with their willing so they "may follow" and so they "will not refuse." These phrases indicate that when a man is chosen, God chooses him but he also voluntarily responds to the call. It is not that cod's choice is based on His foreknowledge of the free choice, but, rather, on cod's knowledge of which calling would effectually elicit the voluntary response which He wants. God sends this effectual calling to precisely those individuals He chooses.

The sentence, "He calls the man on whom he has mercy in a way he knows will suit him, so that he will not refuse the call," combines all of the elements I have pointed out. First, God knows what call will suit the man. In other words, He knows that the man would respond if a certain call is given and that he would not if another call is given. second, it is this knowledge that is the basis for cod's sending one type of call rather than another in order to achieve His desired result. Third, since cod knows how the man would respond to different calls, the call that He sends is suited to the individual and the individual will freely respond. The effectual call elicits a voluntary 
response but it is the response that God wills. It does not go against the will of the individual and it could not go against cod's purpose. Augustine's overriding concern in this section is to show that God's choice is not dependent on the human will but on His own choice to bestow mercy. That he has successfully preserved this is evident in the fact that God sends whichever calling He wills in order to get the result He chooses. If He wishes to have mercy on a man, He sends a call He knows will be effectual. If He chooses to not extend his mercy, he will send a call which He knows will not be effectual. That any individual is chosen, then, is not up to that individual, even though the individual freely responds to the call. It is due to cod's mercy in sending the effectual call that He knew would elicit the free response. The fact that God calls some individuals in a way He knows will be effectual raises questions about why He would not call every person effectually and why He calls certain individuals effectually and leaves others with a non-effectual call. In the context of the passage in Romans, the question is, "why was not Esau called in such a way that he would be willing to obey?"139 Augustine denies that it was impossible for God to call him in this manner. He writes, "who would dare to affirm that God has no method of calling whereby even Esau might have applied his mind and yoked his will to the faith in which Jacob was justified?"10 what the scripture may refer to as the hardening of a person's heart comes from a divine penalty for sin.

$\begin{array}{ll}39 & \text { Ibid., I, Q. 2, } 14 . \\ 40 & \text { Ibid. }\end{array}$


But if the obstinacy of the will can be such that the mind's aversion from all modes of calling becomes hardened, the question is whether that very hardening does not come frcm scme divine penalty, as if cod abandons a man by not calling him in the way in which he might be moved to faith. Who would dare to affirm that the amipotent lacked a method of persuading even Esau to believe? ${ }^{41}$

By this hardening of a person's beart, Augustine does not mean that cod makes a righteous person become unrightecus. He acts unjustly to no one. Rather, "the hardening which cod causes is an umillingness to be merciful. We must not think that anything is imposed by cod whereby a man is made worse, but only that he provides nothing whereby a man is made better."12 cod simply chooses not to provide the effectual call that is necessary in order for the person to respond in faith and receive justification. This is not unjust in that cod is not withholding anything that is cue the individual. In those instances where cod does choose to call effectually, this gift of mercy is purely an undeserved gift of grace.

Augustine acknowledges that this is difficult to accept. Anyone might be tempted to raise the objections the apostle himself raises, 'Thou wilt say then unto me, Why doth he still find fault? For who withstandeth his will?"13 In response, Augustine argues that it is not unjust for cod to have mercy on some but to withhold mercy from others. It is true that whatever reason there may be for His choice of one individual over another is beyond the mman ability to understand. Augustine's argument for the justice of cod proceeds from a comparison with ordinary human society in which there are many transactions, scme 41 Ibid. Alugustine is quoting Romans 9:19. 
of which consist of debts. No ane is considered unrighteous or unjust for expecting payment for a debt. On the other hand, if the creditor wishes to forgive a particular individual's debt, this also does not violate justice. Augustine points out that, "This decision does not lie with those who are debtors but with the creditor."14

This common occurrence in mman society is similar to God's dealings with mmanity. Augustine writes:

Now all men are a mass of sin, since, as the apostle says, "In Adam all die" (I Cor. 15:22), and to Adam the entire mman race traces the origin of its sin against cod. sinful mumity must pay a debt of punishment to the sumreme divine justice. Whether that debt is exacted or remitted there is no unrighteousness. 45

The critical point is that God does not cause any person to sin. Both the one who receives mercy and the one who does not are deserving of the punishment. The only difference is that God chooses to remit the debt of the one and to exact the debt of the other. This is also a different view of original sin than that which we observed in De libero arbitrio III. ${ }^{16}$ Here, Augustine implies that it is something more than moral difficulty (or the disposition to form certain habits of the soul) that is inherited. Guilt, which merits divine pumishment, is also passed down from Adam to all of his descendents.

To be sure, no one resists his will. Both be who is aided and he who is left belong to the same mass of sin. Both deserve the punishment which is exacted from the one and remitted to the other.... Only let us hold fast with unshakable faith the fact that there is no unrighteousmess with God; so that, whether be remits or exacts the debt, he cannot rightly be charged with unrighteousness

$\begin{array}{ll}44 & \text { Ibid.., I, Q. 2, } 16 . \\ 45 & \text { Ibid. } \\ & \text { See PP. } 68-70 \text { above. }\end{array}$


by him from whom he exacts it; and he who receives remission ought not to glory in his own merits. The former pays back nothing but what he owes, and the latter has nothing that be has not received. 47

At this point, Augustine has concluded that two statements which are in seeming conflict are actually both true. The firgt statement is that God's alection of Jacob and his rejection of Esau was prior to and not influenced by their works (good or evil), their faith (or lack of faith), or any other distinction between them. This is completely a result of the free choice of cod. secondly, it is true that there is no injustice in God's choice. Electing one and rejecting another is entirely just.

The next apparent difficulty Augustine seeks to resolve consists of two scripture verses. One reads, "Thou hatest nothing that Thou hast made."48 The second is "Jacob I loved, but Esau I hated." (Romans 9: 13). Augustine claims that God does not hate Esau the man, who is a creation of cod and is therefore good. Cod hates the sin which is a perversity of the good nature which cod created. As Augustine writes, IGod does not hate Esau the man, but Esau the sinner.... They are both men and sinners, men as fashioned by God, sinners by their own wills."199 In this way cod does not hate anything He has made, He only hates the evil which is not a created thing at all.

As he sumarizes his explanation of the difficulties in Romans 9, Augustine returns to the theme of the book, that is, that no one has

47
48
Al simp. I, I. 2, 17.
verse, I could not find the reference, even after
consulting two exhaustive concordances.
Ibid., I, Q. 2, 28.


rocm for boasting before cod. He writes, "Ihe apostle, therefore, and all those who have been justified and have demonstrated for us the understanding of grace, have no other intention than to show that he that glories should glory in the Lord. ${ }^{150}$ Augustine then asserts some of the implications of his interpretation for the notion of free will:

Free will is most important. It exists, indeed, but of what value is it in those who are sold under sin? ... We are conmanded to live righteously, and the reward is set before us that we shall merit to live happily for ever. But who can live righteously and do good works unless he has been justified by faith? We are commanded to believe that we may receive the gift of the Boly spirit and become able to do good works by love. But who can believe unless he is reached by some calling, scme testimony borne to the truth? Who has it in his power to have such a motive present to his mind that his will shall be influenced to believe? who can welcome in his mind something that does not give him delight? But who has it in his power to ensure that something that will delight him will turn up, or that he will take delight in what turns up? If those things delight us which serve our advancement towards God, that is due not to our own whim or industry or meritorious works, but to the inspiration of God and to the grace which he bestows. He freely bestows upon us voluntary assent, earnest effort, and the power to perform works of fervent charity. 51

In light of Augustine's interaction with this passage in Romans, his notion of free will, at this point, is not that of a will with the freedom of indifference. In other words, an individual does not have the ability to choose and perform what is right apart from God's intervention. The will, here, is free in that it is voluntary. When an individual chooses to believe, that is a voluntary choice. It is not autonomous since it is God that gives the desire so to choose and bestows the effectual call. It is voluntary in that it it is in accordance with the individual's desires. It is not inposed from some 
external compulsion. God gives the voluntary assent.

since the fall of Adam, all mumans are enslaved to sin. This means they cannot, of their own initiative, choose to become and to do good. This freedom, which existed in Adam, was lost when Adam sinned. Free will remains but it is of no belp unless God intervenes. This is seen in the above passage where Augustine writes, "Of what value is it [free will] in those who are sold under sin?" Only if God, in His mercy, chooses to effectually call an individual will that person be able to respond to His grace.

The only possible conclusion is that it is wills that are elected. But the will itself can have no motive unless samething presents itself to delight and stir the mind. That this should happen is not in any man's power. ${ }^{2}$

It is, however, in the power of cod to "delight and stir" the mind of anyone He chooses in such a way that they will voluntarily respond in faith. In light of our study, we see that Augustine is bolding a compatibilist view of the freedom of the will. It is possible for the individual to choose to turn to God only if a specific antecedent condition is changed. This is the presence of God's mercy expressed in an effectual call. Onless God calls in this way, the person cannot will to turn. If cod does call effectually, the person cannot refuse to will to turn. God's effectual call, then, is both a necessary and a sufficient condition for the individual's turning to God.

Augustine is not denying the freedom of the will. The will is free even if the choice to turn to cod is not within the power of the 52 Ibid., I, Q. 2, 22. 
individual. It is free because it is voluntary. If a person turns to cod, that turning is in accordance with the person's will. If the person does not turn, the not turning is in accordance with his or her will. Turning or not turning is never imposed against the will of the individual.

In this work, Augustine's use of the term "voluntary" is different from that in his earlier works. Rather than the freedom to do otherwise, or the freedom of indifference, "voluntary" now means "in accordance with the will." Where "voluntary" and "necessary" were contraries, in De libero arbitrio, ${ }^{53}$ now they are not. A choice can be necessary and voluntary at the same time. If cod does not grant an effectual call, a person's failure to turn to cod is necessary. This is because it was not within his or her power to turn to God. This failure is also voluntary because it is in accordance with (not opposed to) the person's will. The heart of the questions Augustine has investigated lies in the very nature and purposes of God, of whom he writes, "But his judgements are inscrutable and his ways past finding out."54

The Freedom of the will in the confessiones

In De diversis quaestionibus ad simplicianum, the case of Jacob and Esau was scrutinized and insights were drawn regarding the freedom of the will. In the confessiones, it is Augustine who is both the examiner and the examined. Looking over his life and growth from early $53 \quad$ For this discussion in Book I see pp. 39, 40; for $54 \quad$ Book III, see pp. 73, 
childhood through his conversion, Augustine paints a picture of total dependence upon cod. The many descriptions of his inner turmoil are vivid illustrations of his perception of the freedom and struggle of his own will. The view that emerges is one from a different perspective than that in the second question of Book I of De diversis quaestionibus ad simplicianum.

De diversis quaestionibus ad simplicianum is a work of exegesis while the Confessiones is a work of introspection and prayer. Using the data of revelation, the former affords a look into the purposes of cod. Using the data of experience, the latter reveals the mman heart. While both works emphasize the individual's dependence on God, De diversis cuaestionibus ad simplicianum explores this from God's perspective and the confessiones views it from that of the individual.

Because of this, there is little speculation in the Confessiones concerning the general questions relating to the freedom of the will. Augustine really does not discuss it at all. Rather, he unveils his deep reflection on his own experience. His agony at being "boumd, not with the irons of another, but my own iron will."155 and his longing for the true freedom which only cod can bring fill and overflow the pages. It is out of this personal story that some abservations about the will's freedom can be made.

Book VIII of the Confessiones is that in which Augustine's struggle reaches a climax. Years of pursuing wisdom through the Nanichaeans, scepticism, and into Neo-Platonism have led him to the doorstep of the Christian faith. He need only to enter. It is perhaps 55 Conf., VIII, 5, 10. 
significant that Book VIII opens with Augustine seeking help from simplicianus. Simpliciamus encouraged Augustine in his reading of the Platonists. He also related the story of the conversion of Victorimus, who was a famous professor of rhetoric and translator of Platonic works. Augustine's reaction to the story was that he 'burned to imitate him. ${ }^{156}$ However, he found himself bound in his will. He felt that his will was sharply divided between the desire to turn fully to cod and the strong inclination to retain control of his life while contiming to satisfy his passions.

Another messenger, Pontitianus, arrived on scme official business. seeing the works of the Apostle Paul on the table, Pontitianus, already a baptized Christian, related the story of Antony, the Egyptian, who travelled widely establishing commmities of monks. Pontitiamus also told of two friends of the emperor who chanced to read the life of Antony and resolved, then and there, to renounce their positions and fortunes for the monastic life. The impact of their story upon Augustine was deep and powerful:

Such was the story of Pontitianus. But Thou, 0 Iord, whilst he was speaking, didst turn me towards myself, taking me from behind my back, where I had placed myself while unwilling to exercise self-scrutiny; and Thou didst set me face to face with myself, that I might behold how foul $\frac{T}{57}$ was, and how crooked and sordid, bespotted and ulcerous. 57

After Pontitianus left, Augustine was deeply troubled. He cried out to his companion, Alypius: 
"What is wrong with us? What is this? What heardest thou? The unlearned start up and 'take' heaven. and we, with our learning, but wanting heart, see where we wallow in flesh and blood! Because others have preceded us, are we ashamed to follow, and not rather ashamed at not following?" 58

Again, it was Augustine's will which waged war within him. He knew that he had to will resolutely in order to enter into cod's will but he felt himself to be staggering and swaying with a divided will. one part seemed to will to enter and the other fought against entering. cod and continence beckoned from one side while his passions beckoned from the other:

The very toys of toys, and vanities of vanities, my old mistresses, still enthralled me; they shook my fleshly garment, and whispered softly, "Dost thou part with us? And from that moment shall we no more be with thee for ever?" ... Yet they did delay me, so that I hesitated to burst and shake myself free from them, and to leap over whither I was called, -an unruly habit saying to me, "Dost thou think thou canst live without them?" 59

Augustine ran to the corner of the garden and cast himself down, weeping bitterly in prayer. Into his thoughts came the voice of a child chanting, "Take up and read; take up and read."60 It came from a neighbor's house. Augustine recounts:

So, restraining the torrent of my tears, I rose up, interpreting it no other way than as a command to me from Heaven to open the book, and to read the first chapter I should light upon..... grasped, opened, and in silence read that paragraph on which my eyes first fell, whot in rioting and drunkenness, not in chamboring and wantonness, not in strife and envying; but put ye on the Lord Jesus Christ, and make not provision for the flesh, to fulfill the lusts thereof." No further would I read, nor did I need; for instantly,

$\begin{array}{ll}58 & \text { Ibid., VIII, 8, } 19 . \\ 59 & \text { Ibid., VIII, 11, } 26 . \\ 60 & \text { Ibid., VIII, 12, } 29 .\end{array}$


as the sentence ended, -by a light, as it were, of security infused into IIy heart, - all the gloom of doubt vanished away. 61

He was finally converted. As we have observed, throughout this work, Augustine is not concerned with asserting and defending a theory of the human will. He is revealing, by his own inner life, the entire person's absolute dependence upon God; including the dependence of the individual's will. This dependence is powerfully illustrated in several passages. For instance:

[H] e appeared to me not more brave than happy, in having thus discovered an opportunity of waiting on Thee only, which thing I was sighing for, thus bound, not with the irons of another, but my own iron will. My will was the enemy master of, and thence had made a chain for me and bound me. Because of a perverse will was lust made; and lust indulged in became custom; and custom not resisted became necessity. By which links, as it were, joined together (whence I term it a "chain"), did a hard bondage hold me enthralled. But that new will had begun to develop in me, freely to worship Thee, and to wish to enjoy Thee, $0 \mathrm{God}$, the only sure enjoyment, was not able as yet to overcome my former wilfulness, made strong by long indulgence. Thus did my two wills, one old and the other new, one carmal, the other spiritual, contend within me; and by their discord they unstrung my soul. ${ }^{62}$

In this passage the word "custam" is consuetudo, which is often translated as "habit."63 Augustine is describing the develogment and the binding power of habit. He is not asserting that the babit produces a final necessity. It is true that habit forms a chain which binds, but it is a chain that can be broken. At this point in the narrative, Augustine's new will is not strong enough to break the chain of habit. The fact that habit can bind does not release the individual who is

$\begin{array}{ll}61 & \text { Irid. } \\ 62 & \text { Irid., VIII, 5, } 10 . \\ 63 & \text { see pp. 50-52 above. }\end{array}$


bound by the habit from responsibility. This is because, as surgustine admits about himself, the person willingly enters into and strengthens the habit. The individual willingly succumbs to habit even if he or she does not sucamb intentionally. Augustine emphasizes that he willingly pursued and fed his own lust and that this lust, so fed, resulted in a strengthened chain of habit. He writes:

And yet it was through me that custom became more combative against me, because I had come willingly whither I willed not. And who, then, can with any justice speak against it, when just punishment follows the sinner? ${ }^{64}$

Augustine did not will to be bound but he willingly came to the place where be would be bound. This is enough to make him responsible. The punishment which follows is just. Another sentence illustrates this, "For the law of sin is the violence of custam, whereby the mind is drawn and held, even against its will; deserving to be so held in that it so willingly falls into it. ${ }^{65}$ once the person is chained by custom (habit- consuetudo), he is held against his will. A person who chooses to satisfy his or her lusts and contimues to indulge in these lusts, becomes bound in them. He or she will contime to strive to satisfy them even if he or she would rather be free of them. Against the desires of the person, the will is bound. This compulsion is still blameworthy because it was entered and embraced voluntarily. A man voluntarily brings himself to a place from where he can only cry out, "IO wretched man that I am! who shall deliver me from the body of this $\begin{array}{ll}64 & \text { Conf.., VIII, 5, } 11 . \\ 65 & \text { Ibid., VIII, 5, } 12 .\end{array}$ 
death' but Thy grace only, through Jesus Christ our Iord?"66

As Augustine grew closer to his conversion, the intensity of his divided will increased. He describes the will which can enter God's will and the will that cannot:

I was disquieted in spirit, being most impatient with myself that I entered not into Thy will and covensent, $O$ my God, which all my bones cried out unto me to enter, extolling it to the skies. And we enter not therein by ships, or chariots, or feet, no, nor by going so far as I had come from the bouse to that place where we were sitting. For not to go only, but to enter there, was naught else but to will to go, but to will it resolutely and thoroughly; not to stagger and sway about this way and that, a changeable and half-wounded will, wrestling, with one part falling as another rose. 67

With a half-wounded will, he fought against himself. He could not will resolutely. Augustine makes a point of observing the difference between the ease with which his body responded to his will's conmand and the difficulty the will itself had in following his desire to will to turn to God. He describes the "monstrous thing"168 of the divided will as follows:

The mind commands the body, and it obeys forthwith; the mind commands itself and is resisted. The mind commands the hand to be moved, and such readiness is there that the command is scarce to be distinguished fram the abedience. Yet the mind is mind, and the the hand is body. The mind commands the mind to will, and yet, though it be itself, it obeyeth not.... But it willeth not entirely; therefore it commandeth not entirely. For so far forth it commandeth, as it willeth; and so far forth is the thing commanded not done, as it willeth not.... For were it entire, it would not even cormand it to be, because it would already be. It is, therefore, no monstrous thing partly to will, partly to be umwilling, but an infirmity of the mind, that it doth not wholly rise, sustained by truth, pressed down by custom. And so there are 
two wills, because one of them is not entire; and the one is supplied with what the other needs.6.

Augustine's conclusion that there are two wills is not to be confused with the Manichaean motion that there are two separate minds in each individual. Augustine digresses to argue this point. He is emphasizing that it is the one sour which is divided in intent rather than that there are two separate souls which are of divided purpose; one being good and the other evil, as in Kanichaeism. The war which raged within him was not between two substances but between his desire to will entirely to turn to God and his refusing to will entirely. He comments that "I neither willed entirely, nor was entirely umilling. Therefore was I at war with myself, and destroyed by myself."10 He concludes this digression against the Manichaean notion of two souls by asserting:

Thus, also, when above eternity delights us, and the pleasure of tenporal goods holds us down below, it is the same soul which willeth not that or this with an entire will, and is therefore torn asunder with grievous perplexities, while gut of truth it prefers that, but out of custom forbears not this. ${ }^{71}$

Assessment

Throughout the period immediately following Augustine's consecration as bishop Augustine held that the human will is unable to turn to God without divine intervention. Both in his exegesis of Romans 9 and in his personal experience he emphasizes the total dependence of

69

70

71

\section{Irid.}

Ibid., VIII, 10, 29. Ibid., VIII, 10, 24. 
the individual upon God. God's mercy intervening is both a necessary and sufficient condition of the will's turning to God. This has been seen in passages in De diversis quaestionibus ad simpliciamm such as the following:

Clearly it is vain for us to will umless God have mercy. But I do not know how it could be said that it is vain for cod to have mercy unless we willingly consent. If God has mercy, we also will, for the power to will is given with the mercy itself. It is cod that worketh in us both to will and to do of his good pleasure. If we ask whether a good will is a gift of God, I should be surprised if anyone would venture to deny that. But because the good will does not precede the calling, but calling precedes the good will, the fact that we have a good will is rightly attributed to cod who calls us, and the fact that we are called cannot be attributed to ourselves. So the sentence, "It is not of him that willeth, nor of him that runneth, but of cod that hath mercy" cannot be taken to mean simply that we cannot attain what we wish without the aid of God, but rather that without his calling we cannot even will. 72

That God's intervention is a necessary condition of the individual's will turning to God can be seen in this passage by the first sentence: "Clearly it is vain for us to will unless God have mercy." Unless cod has mercy, our willing is in vain. It cannot be efficacious. That God's mercy is a sufficient condition is seen from the sentence: "If God has mercy, we also will, for the power to will is given with the mercy itself." If cod's mercy is present, as an effectual call, the individual will certainly will to turn to God. It is not in the power of the individual to refuse to turn if cod supplies the mercy. This is the meaning of the sentence: "But I do not know how it could be said that it is vain for God to have mercy unless we willingly consent." Another passage that alludes to this is the 72 Ad simp., I, Q. 2, 12 . 
Those are chosen who are effecturlly called. Those who are not effectually called and do not obey their calling are not cbosen, for although they were called they did not follow.... .For, although he calls many, he has mercy on those whom he calls in a way suited to them so that they may follow. But it is false to say that "it is not of God who hath mercy but of man wo willeth and Iumneth," because God has mercy on no man in vain. He calls the man on whom he has mercy in the way he knows will suit him, so that he will not refuse the call. 73

Again, Augustine is emphasizing that, once the effectual call is given, the man cannot refuse. This is because an effectual call is by definition the call that cod infallibly knows will elicit the response of faith. Augustine writes that "cod has mercy on no man in vain." The effectual call of cod can thus be seen to be a sufficient condition of the muan will's turning to cod. It is also, as we have seen, a necessary condition. This too can be seen in this passage. The first two sentences explain that only if the effectual call is present can the individual be said to be "chosen." Those who are not effectually called are not chosen and they do not respond.

Augustine is clearly bolding the compatibilist position on the Ereedom of the will, as we bave described it. ${ }^{74}$ This is also implied in the Confessiones. While there is no systematic treatment of the freedom of he will, nowhere does Augustine imply that the turning to God was up to him and within his power. Rather, we hear him cry out in his utter dependence upon God's mercy:

And, not indeed in these words, yet to this effect, spake I mach 
unto Thee, "But Thou, O Iord, How long?" "Blow long, Lord? Wilt Thou be angry for ever? Oh, remember not against us former iniquities;" for I felt that I was enthralled by them. I sent up these sorrowful cries, aliow long, how long? Tomorrow, and tomorrow? Why pot now? Why is there not this hour an end to my uncleanness?"75

\section{Summary}

During the first years of Augustine's life as a bishop, the develogment of his view of the freedom of the will has reached a very different position from that which he bad previously beld. There are five brief observations to be made. First, a choice is free if it is voluntary. The use of the word "voluntary" here is different from the use in previous periods. Rather than implying the freedan of indifference, a voluntary act is one which is in accordance with the individual's will whether or not the individual could have acted otherwise. In this sense, Augustine now held that an act could be both necessary and voluntary at the same time. It is necessarily true that, without the intervention of cod, a person can not turn to Him in faith. The person's not turning is, however, voluntary. That is, it is not against the person's will.

The second observation is that, as in the previous periods, Augustine, at this time, still held that it was part of the essential nature of sin that it be voluntary. This voluntary nature of sin is what brought responsibility. An individual is responsible for an act if it was a voluntary act. Even if it was not within the individual's power to turn to God, because his or her not turming was in accordance 75 Conf., VIII, 12, 28. 
with his or her will, the individual is responsible for the fact that he or she did not turn to God.

The third observation is that divine intervention is both a necessary and sufficient condition for an individual to turn to God. Unless cod intervenes by bestowing mercy, it is impossible for the individual to turn to God. It is beyond the ability of the individual to turn to God unless God first gives the person faith. If God intervenes by extending His mercy to an individual, that individual will turn to God. This is because the mercy of God includes an effectual call of that individual. The call is effectual because God knows what call would be such to elicit the response of faith. God sends this effectual call to the individual on whom He chooses to have mercy and the person responds in faith.

The fourth observation is that Augustine is very concerned with defending the notion that each individual is completely dependent upon God. His exposition of Romans 9 and his explanation of his own experience both overflow with this theme. The individual's dependence upon God is consistent with the above observations that divine intervention is both a necessary and a sufficient condition for a person's turning to cod.

The fifth observation is that it appears to be more difficult, given this latest view, to hold that the origin and responsibility for evil can be traced to man and not cod. If cod's choice to send an effectual call is based solely on His own will, no individual can be held responsible for the type of call he or she receives. If an effectual call is both a necessary and sufficient condition for a 
person's turning to God, it is difficult to see how the individual could be in any way blameworthy if he or she failed to turn to cod. The view that the individual was free because the not turning was in accordance with the individual's will, does not seem to alleviate the difficulty. It would seen to be a difficult task to apply the view Augustine appears to hold during the early years of his episcopacy to the problem of evil.

In the next chapter, we shall see how three specific factors contributed to the development of Augustine's view of the freedom of the will throughout the period we have traced. The first contributing factor is the increase in Augustine's reliance upon and familiarity with the scriptures. This came about as a result of his outies as a priest and bishop. The second factor is his observations about his own moral and spiritual struggle. The last factor is his confrontation with the moral and spiritual struggle of his parish. These influenced him to recognize the role of habit and the role of God's intervention in the individual's life. 
CFAPTER V

TNFLUEACES ON THE DEVELOPMENT OF ADEUSTINIE'S

VIEN OF THE FREEDOM OF THE WIIL

We have traced how Augustine's view of the freedom of the will developed throughout the period between his conversion to Christianity in 386 and his early years as bishop. In the first few years after becoming a Christian, Augustine held an incompatibilist view. That is, he held that it is within an individual's power, without any change in antecedent conditions, either to turn to cod or to turn away. specifically, he held that God's intervention was not necessary to enable an individual to turn to God. After becoming a priest, Augustine began to recognize the power that habits had in hindering the will of a person. Shortly after he was consecrated as bishop, he began to bold the compatibilist view in that God's intervening mercy was both a necessary and a sufficient condition for an individual's turning to God.

As we abserve the changes in his life calling throughout this period, three themes emerge which it is reasonable to postulate as influences that led to this development in Augustine's view of the freedom of the will. These are the influence of the scripture, that of Augustine's own moral and spiritual struggle, and that of his pastoral 
work of trying to help his congregation live morally and spiritually. In this chapter I shall briefly explain each of these themes and I shall show how each of these may have played some role in the development of Augustine's position regarding the freedam of the will.

The Influence of scripture

Although Augustine was acquainted with the scriptures throughout his life and had come to embrace them as authoritative, when be became priest he felt a desperate need to understand and use them properly. He wrote to his bishop, Valerius, pleading for time to study the Bible both for his own spiritual health and in order to be equipped for the work of the ministry. His immersion in the sacred writings contimued throughout his life and shaped his thought to a mach greater degree than the other influences which we shall consider.

It is clear that Augustine's perception of his need for the scriptures was not tenporary. He became increasingly preoccupied with the Bible and with making the meaning of the text clear. He published sermons, letters and formal treatises explaining this or that passage to his audience. Augustine's heavy reliance on the scriptures is evidenced by the huge outpouring of exegetical works which occurred a very few years after his ordination. As Teselle observes:

A sudden surge of interest in the epistles of paul becomes apparent about 394. In quick succession Augustine wrote an Exposition of Eighty-Four Propositions on the Epistle to the Ramans, then an Brposition of the Epistle to the Galatians, then an unfinished Bxposition of the Epistle to the Romans, as well as discussions of pauline problems in questions 66 through 68 of the 
collection of responses to various questions. ${ }^{1}$

These works, coupled with the many sermons be preached including the first thirty-two of the Fnarrationes in Psalmos and the De sermone Damini in monte, further illustrate his growing preoccupation with the Bible. ${ }^{2}$ Baboock points out how it was Augustine's study of st. Paul and particularly of Romans 9 that caused the change in his position on the freedom of the will. He writes that "Beyond that, one may add, it was precisely his study of and writing on the Pauline text that became a vehicle for a fundamental shift in his views on the interaction between God's grace and man's freedom."13

In light of this, I shall sketch Augustine's treatment of Romans 9 as it is found in De diversis quaestionibus LXXIII question 68 and Expositio quarundam propositionum ex Epistola ad Romanos propositions 60-62. I shall compare this with his treatment in De diversis quaestionibus ad simplicianum Book I question 2 which we discussed above.

\footnotetext{
1 Euggene Teselle, Auxgustine the Theologian (Herder and Herder, 1970), p. 156.

2 William S. Baboodk, "Auxgustine's Interpretation of Romans (A.D. 394-396)," Augustinian studies Vol. 10 (1979) p. 56, note 4.

3 Baboock, "Augustine's Interpretation of Romans (A.D. 394-396)," p. 56.

4 Baboock in "Augustine's Interpretation of Romans," p. 63 note 29 , places De diversis quaestionibus LxoxIII as chronologically prior to Expositio guarundam propositionum ex Epistola ad Romanos, although be admits "The relative dating is not secure." I shall follow his order.
} 
In question 68 of De diversis quaestionibus LXXXIII Augustine treats the verse, "Oh Man, who are you to talk back to God?" 5 In doing so he refers to much of the same portion of Romans 9 to which he will return two years later in De diversis quaestionibus ad Simplicianum. This, however, is his first treatment of this chapter which is so central in understanding the means and purposes by which God chooses individuals.

since one person is chosen by God and another is not chosen, Augustine reasons, there must be same distinction between them. Where this distinction is located is of central concern. As we saw in Chapter IV, in his expositing this text for simplicianus, Augustine locates the distinction in the free choice of God. There was no distinction in the individuals themselves which would warrant God's choosing one and not the other. In this earlier treatment, however, Augustine maintained that this distinction must be somewhere in the individual. He writes:

By all means he has mercy on whom he wants, but this will of cod cannot be unjust. For it springs fram deeply hidden merits, because, even though sinners thenselves have constituted a single mass on account of the sin of all, still it is not the case that there is no difference among them. Therefore, although they have not yet been made righteous, there is scme preceding thing in sinners whereby they are rendered worthy of righteousness, and again, there is same preceding thing in other sinners whereby they are deserving of obtuseness. You have the same Apostle saying elsewhere: "Because they did not see fit to have a knowledge of God, God gave them up to an unsound mind." cod gave them up to an unsound mind- this is how He hardened Pharoah's heart, and they did not see fit to have a knowledge of God-this is how they showed 
themselves worthy of being given up to an unsoumd mind. 6

Augustine is clearly attributing God's choice of one and rejection of another to the merits of the individuals, even if these are "deeply hidden." The difference between bow cod deals with one individual and how He deals with another results from some difference that is within the individuals. Augustine does not explain, in this passage, exactly what the difference is which results in different merits, but only that it is "some preceding thing" which merits either righteousness or obtuseness.

Augustine makes a point of asserting that this is not in conflict with the scripture which says that "'it is not of him who wills nor of him who runs, but of God who shows mercy'"17 It is here, in arguing this point, that Augustine explains what the difference is within the individuals which warrants different treatments by God. He explains:

For even if each person with petty sins or gemuinely grave and numerous sins, however many, is yet worthy of God's mercy by virtue of a great lament and the anguish of repentance, this does not depend on himself, who would perish if abandoned, but on God who shows mercy and who comes in response to his prayers and anguish. For it is not enough to will except cod show mercy; but cod, who calls to peace, does not show mercy except the will have preceded, because on earth peace is to men of good will. And since no one can will unless urged on and called, whether inside where no man sees, or outside through the sound of the spoken word or through some visible signs, it follows that God produces in us even the willing itself. 8

\footnotetext{
6 De diversis quaestionibus IXXXII 68,4 , trans. David I. Kosher in The Fathers of the Church, Vol. 70. (Washington D.C.: Catholic University Press,

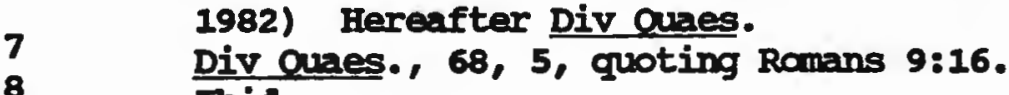

8 Ibid.
} 
Apparently it is "by virtue of urgent lament and the anguish of repentance' that an individual becomes worthy of cod's mercy. But, as Augustine insists, the individual's salvation is in no way dependent upon the individual. If a person were left alone, be or she would be left in sin and would perish. Only because God shows His mercy is a person rescued. God shows His mercy "in response to his prayers and anguish." The critical sentence in this passage is "For it is not enough to will except cod show mercy; but God, who calls to peace, does not show mercy except the will have preceded..." Here Augustine summarizes his system. First, it is impossible to will to be righteous and to attain it without God's mercy. This is clearly in opposition to his earliest views which we discussed in which it appeared to be possible to independently will to live rightly.9 Augustine, here, preserves the view that the individual is dependent upon cod for salvation.

The second point in his system is that the will of the individual precedes Cod's showing mercy. This is consistent with the position which we observed in De libero arbitrio Book III (written about the same time) in which it was possible for the individual to turn to God in order to receive divine aid, without His intervention. No intervention was needed for the turning but only after divine intervention was it possible to live rightly. As we saw, by the time Augustine wrote De diversis quaestionibus ad simpliciamm, he held that the actual turning to God was also included in the mercy of cod.

In De diversis quaestionibus IXXXII question 68, Augustine beld

9 see pp. 40-41 above. 
that the human will precedes cod's mercy. God has mercy on those who will to turn to Him. The individual's turning is not enough to merit righteousness, however. Only the mercy of God can bestow righteousness. This mercy is merited by an individual when he or she wills to turn to God. In this way the difference which results in some individuals being chosen by God and others not being chosen resides in the individuals' wills.

Romans 9 in Expositio quarumdam Propositionum ex Epistola ad Romanos

In Augustine's work Expositio quarumdam propositiomm ex Epistola ad Ramanos 60-63, he traces the same portion of Romans 9 which he dealt with in De diversis quaestionibus IXXXII and De diversis quaestionibus ad simplicianum. This work was written very close to the same time as the former and, as a result, there is little difference in Augustine's explanation of the text. Augustine writes:
"For when they were not yet born, nor bad they done anything either good or evil, in order that the purpose of God's election might contimue, not because of works but because of his call, she was told, 'the elder will serve the younger', as it is written, 'Jacob I loved, but Esau I hated.'" This moves some people to think that the apostle Paul had done away with the freedom of the will, by which we earn the esteem of God by the good of piety, or offend him by the evil of impiety. For, these people say, God loved the one and hated the other before either was even born and could have done either good or evil. But we answer that cod did this by his foreknowledge, by which he knows the character even of the unborn. "10

Expositio quarundam propositionum ex Epistola ad Romanos, 60, 1, trans. Paula Fredriksen Landes (Chico, Calif.: scholars Press, 1982) Hereafter Prop ad Rom. 
several things must be observed about this passage. First, and most abvious, Augustine insists that Paul did not eliminate the freedom of the will. Becond, it is by the freedom of the will that an individual either earns cod's esteem or offends Him. Third, though the scripture indicates, "God loved the one and bated the other before either was born," God is not unjust. He has foreknowledge, even before they are born, of their future faith or impiety. cod's loving the one and hating the other seems to be a response to the faith or impiety which He foreknows they will have. In this case, the faith or the impiety seems to be within the individual's power independent of cod's working in the individual's life.

Augustine rejects the notion that it might be the future good works of an individual which cod foreknows and to which He responds. Augustine simply states, "If God elected works, why does the Apostle say that election is.not according to works?"11 since it is not the foreknowledge of good works which causes cod to love the one, the role of good works must be explained:

For this very reason, then, one should understand that we are able to do good works through love, and we have love through the gift of the Holy spirit, as the Apostle himself says: "For the love of cod has been poured into our hearts by the Holy spirit, which has been given to us" (5:5). Therefore no one should glory in his works as though they were his own, for he does them by the gift of cod, since this love itself works good in him. What then has cod elected? For if he gives the Holy spirit, through whom love works good, to whomever he wishes, how does he choose the spirit's recipient? If he does not choose according to merit, it is not election, for all are equal prior to merit, and no choice can be made between absolutely equal things. But since he gives the Holy spirit only to believers, cod indeed does not choose works, which he himself bestows, for he gives the spirit freely so that through love we might do good, but rather he chooses faith. For unless each Ibid., 60, 4. 
one believes in him and perseveres in his willingness to receive, he does not receive the gift of God, that is, the Holyy spirit, whose pouring forth of love enables him to do good.

To do good works is a gift of God. They are a result of and not prior to God's intervention. Augustine insists, therefore, that it is not future good works which merit election. Augustine is assuming here, as in question 68 of De diversis quaestionibus IXXXXIII, that there must be a distinction between individuals in order for God to be just in choosing one over another. He indicates this by the sentence, "If He does not choose according to merit, it is not election, for all are equal prior to merit, and no choice can be made between absolutely equal things." This distinction is located in the individuals themselves. It is not their good works, since works come from the Holy Spirit. Rather, since it is to believers that He gives His Holy Spirit, Augustine concludes that it is faith which cod chooses.

Augustine discusses the relationship between cod's call and man's free response:

Moreover, the nature of grace is such that the call precedes merit, reaching the sinner when he had deserved only damation. But if he follows God's call of his own free will, he will also marit the Holy Spirit, through whom he can do good works. And remaining in the spirit -no less also by free will- he will also merit life eternal, which cannot be marred by any flaw. ${ }^{13}$

God's call comes first. The sinner does not initiate or deserve the call and therefore the call that is extended is an expression of God's grace. Once the call is given, the individual responds "of his 
own free will." This free response merits the gift of the Holy spirit and the subsequent ability to do good works. Here, as in his other treatments of Romans 9, Augustine attempts to reason in a manner consistent with Ramans 9:15, "'Therefore it depends not on man's willing or ruming, but on God's mercy."'14 He writes:

Paul does not take away the freedom of the will, but says our will does not suffice unless God helps us, making us merciful so that we can do good works through the gift of the Holy spirit, as he had just said above, "I will have mercy on whon I will have had mercy, and I will show him compassion on whom I will have had compassion." For neither can we will unless we are called, nor after our calling, once we have willed, is our will and our running sufficient unless God both gives strength to our rumning and leads where he calls. Therefore, clearly, we do good deeds not by our own willing or running but by the mercy of God, afthough our will (which alone can do nothing) is also present. ${ }^{15}$

Augustine emphasizes that the freedam of the will is preserved. However, the will is not able to choose and attain right living without God's intervention. Only cod can enable a person to accomplish good works. A person's willing, although free, is not totally independent of God's work in the person's life. Augustine holds that it is in response to the initial call of cod that a person freely wills to respond.

In both of these early works on Romans 9, Augustine insists that an individual's will can turn to God in response to His calling or the individual can refuse to respond by turning. Augustine does not distinguish between an effectual call and a non-effectual call, as he does in his De diversis quaestionibus ad simpliciamm. The distinction which warrants the election of one and the rejection of another is

Tbid., 62, 1, quoting Romans 9:15. Tbid., 62, 1-4. 
located in the individuals themselves. It is their faith or lack of faith which determines their destinies.

Romans 9 in De Diversis Quaestionibus ad simpliciamm

Although we have already given a great amount of attention to Augustine's exposition of Romans 9 in De diversis quaestionibus ad simplicianum, a brief overview of some key points will help highlight how Augustine's use of the scriptures influenced the development of his thought concerning the freedom of the will. It must be remembered that this text was written only two years after those which we have just discussed. The central issue in comparing these three treatments of Romans 9 is where Augustine locates the distinction which warrants the choosing of some individuals and the rejection of others.

We $\operatorname{saw}^{16}$ that Augustine, in this latest work, rejects the idea that the distinction between individuals is the faith that God foreknows one will have and the impiety that God foreknows that the other will have. The distinction is not within the individual at all. It is entirely within God's purposes and free choice. G.R. Evans writes:

By the time he had composed his answer to question Two, he had thought again about the passage in Romans (9:11) where Paul says that God loved Jacob and hated Esau before either was born. This led him to the view that God must make His choice before the individual is in a position to turn to God of his own volition. It follows that man is given two things by grace: first the power to will, and then the power to do what is willed. 17 
Augustine writes:

There could be no election on account of good works, according to which the purpose of God might stand. Bo "not of works but of him that calleth," that is, of cod who justifies the ungodly by grace calling him to faith, "it was said to her, the elder shall serve the younger." so that the purpose of cod does not stand according to election, but election is the result of the purpose of cod. ${ }^{18}$

Election is not according to works, faith or anything within the individual. It is entirely according to cod's purpose. cod chooses to save one and leave another. As we have seen, He sends an effectual calling to all those He chooses. He may send a non-effectual calling to those He does not choose or, to scme, He may send no calling at al1. 19 In this cod is completely just. He bestows the mercy of forgiveness on some and not on others. It is analogous to muman transactions in which a creditor might choose to remit some debts and not others. Justice is not compromised and mercy is expressed.

By comparing Augustine's approaches, in three different works, to the same passage of scripture, it can be seen how his interaction with the text and his work at discovering its meaning influenced him to shift his position. Beyond this, however, there are places where he explicitly admits that it was his attention to the scripture which aided this develogment. The first of these is the oft-quoted text in

Ad Bimp., I, $2.2,6$. Augustine does not say whether cod sends scme type of calling to every individual, in which case all those whom He does not choose would receive non-effectual callings, or whether same get non-effectual callings and scme no calling at all. 
the Retractationes in which he describes his working on De diversis quaestionibus ad simplicianum, "In the solution of this question, I, indeed, labored in defense of the free choice of the mman will; but the grace of God conquered...."20 This indicates that it was the very act of laboring over these scriptures in the writing of this work which was the occasion of his change in view.

Another passage that indicates that it was the scripture which aided the development of Augustine's thought is found in chapter seven of De praedestinatione sanctorum. Although the whole chapter consists of Augustine's review of his former position and a defense of his mature view from the scriptures, I shall only cite a portion:

For I did not think that faith was preceded by God's grace, so that by its means would be given to us what we might profitably ask, except that we could not believe if the proclamation of the truth did not precede; but that we should consent when the gospel was preached to us I thought was our own doing, and came to us from ourselves. And this my error is sufficiently indicated in some small works of mine written before my episcopate.... I had not very carefully sought, nor had I as yet found, what is the nature of the election of grace, of which the apostle says, "A remnant are saved according to the election of grace." Which assuredly is not grace if any merits precede it; lest what is now given, not acoording to grace, but according to debt, be rather paid to merits than freely given. 21

Augustine, here, attributes his error to the fact that he had "not very carefully sought." In the context, he is writing about seeking in the scriptures. In fact he highlights scriptural tests which influenced his changes in thought. Assertions likes these, and the abvious shift

Retr., II, 27.

De praedestinatione sanctorum III, 7, trans. Robert Frnest Wallis in A select Library of Nicene and Post-Nicene Fathers, Vol. V, (Edinburgh: T\& $T$ Clark, reprint Grand Rapids, Mich.: Eerdmans, 1987) 
in his exegesis of Romans 9 support the view that the sariptures played a large role in the development of his views on God's grace and mman freedom.

The Influence of Augustine's

Personal woral struggle

During the first years after Augustine was converted to Christianity, he retained mach of his Neo-Platonist perspective on the spiritual develogment of the individual. This included the notion of a progressive and contimuous spiritual ascent. It was hoped that happiness of the soul would be attained and enjoyed in this life. In fact, Augustine scmetimes wrote as if it was not too far off in the future. As the years progressed, however, and especially after he became a priest, these early aspirations were seen as impossible. As Peter Brown abserves:

Ten years later this great hope had vanished. "Thoever thinks", Augustine will then write, "that in this mortal life a man may so disperse the mists of bodily and carnal imaginings as to possess the unclouded light of changeless truth, and to cleave to it with the unswerving constancy of a spirit wholly estranged from the common ways of life -he understands neither what he seeks, nor who he is who seeks it." [de cons. evang. IV, x, 20]

Augustine, indeed had decided that he would never reach the fulfillment that he first thought was promised to him by a Christian Platonism: he would never impose a victory of mind over body in himself, he would never achieve the rapt contemplation of the ideal philosopher. It is the most drastic change that a man may have to accept: it involved nothing less than the surrender of the bright future he thought he had gained at cassiciacum. 22 
Augustine came to see that the difficulty which plagues the mman will is much more severe than his Neo-Platonism would have thought possible. As he reviewed his life and spiritual pilgrimage in the Confessiones, mumerous passages leap out to attest to this difficulty. In one place he describes how a binding habit was developed:

[H] appeared to me not more brave than happy, in baving thus discovered an opportunity of waiting on Thee only, which thing I was sighing for, thus bound, not with the irons of another, but my own iron will. My will was the enemy master of, and thence bad made a chain for me and bound me. Because of a perverse will was lust made; and lust indulged in became custom [consuetudo or "habit"]; and custom not resisted became necessity. By which links, as it were, joined together (whence I term it a "chain"), did a hard bondage hold me enthralled. 23

As Augustine describes the progression from the perverse will to lust, from lust to custom and, finally, from custom to necessity, he is not asserting a theory about sin as much as he is sharing his own experience. He states that it was he himself who was sighing for the opportumity to serve cod. It was his will which bound him as with iron. He goes on and writes that "Imus I came to understand, from my own experience, what I had read, how that 'the flesh lusteth against the spirit, and the spirit against the flesh. "1,24 These are not the reflections of a man who is optimistic about attaining spiritual completion in this life, let alone the near future.

While it is true that the confessiones give us an inside look at Augustine's reflections on his own life and struggles, his experience of his own moral struggle can also be gleaned from passing references 
in his correspondence. For example Augustine writes with great insight on the power and subtlety of pride:

For the man who has not declared war against this enemy has no idea of its power; for if it be comparatively easy to dispense with praise so long as it is denied to him, it is difficult to forbear fram being captivated with praise when it is offered.... and yet, although stremuously contending with my adversary, I often receive wounds from him when I am unable to put away from myself the fascinating power of the praise which is offered to me. 25

Pride was a sin which Augustine knew from the inside, not as he knew the sins of his past which were put away upon his conversion, but as a very present threat. Another sin to which he was tempted was anger. He reveals to Profuturus the relationship between anger and hatred. His writing has the flavor of one who is, himself, still struggling to be right in this area:

And well do you know, my excellent brother, how, in the midst of such offences, we must watch lest hatred of any one gain a hold upon the heart, and so not only hinder us from praying to God with the door of our chamber closed, but also shut the door against cod Himself; for hatred of another insidiously creeps upon us, while no one who is angry considers his anger to be unjust. For anger babitually cherished against any one becomes hatred, since the sweetness which is mingled with what appears to be righteous anger makes us detain it longer than we ought in the vesgel, until the whole is soured, and the vessel itself is spoiled. ${ }^{26}$

While these are examples of Augustine's own moral struggles, in other places, he explicitly asserts that spiritual growth is a process which is never complete in this life. He writes to Jamuarius that, "this is not actually completed in us so long as we are still 'groaning

$26 \quad$ Ip.. 22, 8.


within ourselves, and waiting for the adoption, to wit, the redemption of our body:...'1127 Augustine's spiritual growth will not be completed in this life. As a result, Augustine urges him to keep in mind that:

[W] e are not to think that we ought to be made happy and free from all difficulties in this present life, and are therefore at liberty to murmur profanely against God when we are straitened in the things of this world, as if He were not performing what He promised.... The new life, therefore, is meanwile begun in faith, and maintained by hope: for it shall only then be perfect when this mortal shall $\frac{1}{28}$ be swallowed up in life, and death swallowed up in victory; ...28

Confronting his own moral struggle and realizing that the babits produced from a life of sin are more powerful than he had previously imagined very well may have contributed to shaping Augustine's perspective on the freedom of his own will. This may also have influenced the development of his theory of muman freedom as well. As he fought against his own shortcomings, he increasingly recognized his need for divine intervention. He needed it himself and he came to see that every person needed cod's grace in order to overcome the habits of the soul and to turn to God.

The Influence of Pastoral Duty

Not only was Augustine confronted with his own moral and spiritual struggle, but his surprising ordination to the priesthood thrust him 
into the daily toil of pastoral life. His days became occupied with settling disputes among the members of his church as well as representing the interests and need of the church to those in civil authority. He also invested a great deal of energy in the sermons he preached and letters he wrote. As he tried to help people live rightly, he was confronted, again, with the sluggishness of the hman will.

We pointed out that, very soon after his ordination, Augustine appealed to valerius for time to study the scripture. He sought this in order to aid his own spiritual growth, but also to be equipped to lead better his congregation. Far from feeling that the pastoral task was an easy situation in light of his own skills and gifts, as he had previously thought, Augustine admits that, "it is true that I did not at any earlier period know how great was my unfitness for the artuous work which now disquiets and crushes my spirit. 129

As to his assessment of his fitness for the task, Augustine writes:

The things which I lack are so many, that I could more easily enumerate the things which I have than those which I desire to have. I many venture to say that I know and unreservedly believe the doctrines pertaining to our salvation. But my difficulty is in the question how I am to use this truth in ministering to the salvation of others, seeking what is profitable not for myself alone, but for many, that they may be saved. ${ }^{30}$

standing before his congregation, Augustine saw a people in various stages of Christian development. Few had apparently made as definitive a break with their pasts as had Augustine. Prendiville

$\begin{array}{ll}29 & \text { Ibid., 21, } 3 . \\ 30 & \text { Ibid., 21, } 4 .\end{array}$


comments:

It is certain that Augustine's people were no angels; according to his sermons and letters they swore, fornicated, got drunk, lied, and were envious and superstitious. Iittle wonder that in this, setting his idea of habit takes on a new and more earthy tone. 31

A specific example of Augustine's struggle with the wills of the individuals in his congregation is recorded in a long letter to Alypius, now bishop of Thagaste. Augustine recounts his persistent preaching against the habit which his congregation had of celebrating the feast of Laetitia in gluttony and drunkenness. His pleading and frustration is evident throughout this letter. He writes:

I asked further, with the deepest sorrow, how it was that, although Noses the servant of cod broke both the tablets of stone because of these rulers of Israel, I could not break the hearts of those who, though men of the New Testament dispensation, were desiring in their celebration of saints' days to repeat often the public perpetration of excesses of which the people of the Old Testament economy were guilty only once, and that in an act of idolatry. 32

Augustine describes his preaching as, "pathetically

reminding", 33 "I charged them to consider...", 34 "I especially begged them...", 35 "And I pled with them...".36 This intensity of preaching finally produced an emotional response in the hearers. Augustine recalls: pp. 61, 62 .

Ep. 29, 4. 
I did not move them to weep by first weeping myself; but while these things were being spoken, I own that, moved by the tears which they began to shed, I myself could not refrain fram following their example. And when we had thus wept together, I concluded my sermon with full persuasion that they would be restrained by it from the abuses denounced. 37

Onfortumately, many of those who wept went back to gluttony and drunkenness the next day. It seemed that Augustine's preaching and pleading had failed. Augustine attributes this return to these sins to the power of the custom:

Next morning, however, when the day dawned, which so many were accustomed to devote to excess in eating and drinking, I received notice that some, even of those who were present when I preached, had not yet desisted from complaint, and that so great was the power of detestable custom with them, that, using no other. argument, they asked, "Wherefore is this now probibited?"138

The custom of sin was so powerful that it led to rationalization. People came up with excuses in order to continue in the very sin over which they had wept only a day earlier. Clearly, Augustine is confronting the weakness of the mman will in a powerfully visible way. This letter is especially valuable because it records both Augustine's attempts at leading his congregation to holiness as well as the response of the people. The grip of the babit was more powerful than the preaching of Augustine and the people's emotional response. Augustine records, however, that eventually those individuals came to grasp his point of view and resisted the temptations to gluttony and drunkenness.

$\begin{array}{ll}37 & \text { Ibid., } 29,7 . \\ 38 & \text { Ibid., } 29,8 .\end{array}$


Another example of Augustine's confrontation with the sluggish will of his congregation concerns the habit of swearing. In his work on the sermon on the Wount, Augustine addresses this as he explains the passage of saripture in which it is written:

"Again," says He, "ye have heard that it hath been said to them of old time, Thou shalt not forswear thyself, but shall perform unto the Lord thine oath: But I say unto you, swear not at all; neither by heaven, for it is God's throne; not by the earth, for it is His footstool; neither by Jerusalem, for it is the city of the great Ring. Neither shalt thou swear by thy head, because thou canst not make one hair white or black. But let your communication be Yea, Yea; Nay, nay: for whatsoever is more than these cometh of evil." 39

Augustine writes of the babit of swearing:

And therefore let him who understands that swearing is to be reckoned not among things that are good, but among things that are necessary, refrain as far as he can from indulging in it, unless by necessity, when he sees men slow to believe what it is useful for them to believe, except they be assured by an oath.... But no one learns, unless he has had experience, how difficult it is both to get rid of a habit of swearing, and never to do rashly what necessity sometimes compels him to do. 40

Swearing is to be avoided as far as is possible. This, Augustine admits, is not easily done. The habit is difficult to overcome. Peter Brown comments, "This campaign against swearing, indeed, would have brought him up against the compulsive force of certain habits, quite as much as any modern campaign against smoking might do."41 Augustine

39 De sermone Damini in monte, I, 17, 51, quoting
Matthew 5:33-37, trans. William Findlay, revised
D. 8. Schaff, in A Select Library of Nicene and
Post-Nicene Fathers, Vol. VI, (Grand Rapids, Mich.:
Eerdmans, 1980) Hereafter De serm mt.
$40 \quad$ De serm mt., I, 17, 51.
Peter Brown, p. 149.


himself points out the difficulty as he concludes the section on swearing, "[w] hat can be named or thought of more laborious and toilsome, where the believing soul is straining every nerve of its industry, than the subduing of vicious habit? 142

These illustrations show how Augustine found his congregation to be seemingly trapped in the binding habits of various vices. His persistent labor in trying to help them overcome these afforded him ample opportunity to observe the power of habits and the weakness of the muman will. It seens reasonable to postulate, since the significant development of Augustine's view of the freedam of the will occurred during the period of his priesthood and early episcopacy, that these abservations comprised one influence on Augustine as his view developed.

In this chapter we have postulated three possible influences on the develogment of Augustine's view of the freedom of the will between his conversion and his writing of the confessiones. His intensive study of scripture, his personal moral and spiritual struggle and his laboring in his pastoral duties all may have contributed to the shift we have observed from the incompatibilist view to the compatibilist view of human freedom.

conclusion

We have traced the development of Augustine's view of the freedom of the will from his conversion to the writing of his confessiones. We 42 De serm mt., I, 18, 54 . 
have found that in the first years after his conversion, he held an incompatibilist view of the freedom of the will. We have seen this in that he believed it was within the power of an individual to choose to turn to cod or to refuse to turn to cod. This act was free if it was voluntary and, at this time, Augustine meant by "voluntary" the freedom of indifference. An act could not be necessary and voluntary at the same time. A person, then, had the ability to turn to cod without any change in antecedent conditions. It was not necessary for the marcy or grace of cod to be present in order for the person to be able to turn to Him.

After Augustine's ordination to the priesthood, we have seen that he still held to this incompatibilist view. He still held that a voluntary act could not be necessary. There must be freedom of indifference. During this period, however, Augustine recognized the power of the habits of the soul to hinder the muan will. It was possible for persons to get to the point where they could not free themselves from the habits they had freely developed. It is always possible to turn to cod for divine aid in order to be free.

After becoming bishop, Augustine began to hold that it was not even possible to turn for divine aid without cod's mercy being present. cod's grace was seen as a necessary and sufficient condition for a person to turn to Him. Augustine had begun to hold the compatibilist view of the freedom of the will.

We have also seen three factors which may have influenced this develogment in Augustine's thought. These are the scriptures, his own moral struggle and the moral struggle he confronted in his 
congregation. with these in mind it is not surprising that Augustine's view of the freedam of the will underwent such a profound development in such a short time.

Augustine's investigation into the freedam of the mman will is marked with a deep desire to find the truth about the matter, as well as a drive to achieve consistency. These are evident in the persistence and thoroughness with which he approaches the topic. His willingness to go over and over the same ground is an admirable demonstration of solid scholarship. He has accomplished the momumental task of setting the problems out with clarity and relevance, as well as of proposing a complex systematic solution. Any investigation into these issues would do well to begin with the saint from Africa. 


\section{BIBTTOERAPHY}

I. Forks of Augustine

Benjamin, Anna s. \& Hackstaff, I. H. trans. On The Free Choice of the Fill. Indianapolis: Bobbs-Yerrill Company, 1964.

Burleigh, J. H. 8. ed. Augustine: Earlier Fritings. The Iibrary of Christian Classics. Philadelphia: Westminster Press, 1953.

The Fathers of the Church. Vol. $3 \& 4$ New York: Iudwig Bchopp, 1948.

The Fathers of the Church. Vol. $60 \& 70$ Washington D.C.: Catholic University Press, $1968 \& 1982$.

Iandes, Paula Fredriksen. Augustine on Romans. Chico, Calif.: scholars Press, 1982.

Schaff, Phillip ed. A select Library of Nicene and Post-Nicene Fathers First series Vol. I-VIII, New York: 1887-1902; reprint Grand Rapids, Kich.: In. B. Eerdmans, 1983.

II. Books

Armstrong, A. H. An Introduction to Ancient Philosophy. Iondon: Methuen \& Co., 1947; reprinted Totowa, N.J.: Rowman \& Allanheld, 1983.

Basinger, David and Randall Basinger. ed. Predestination and Free Fill. Downers Grove, Ill.: Inter Varsity Press, 1986.

Berofsky, Bermard. ed. Free Will and Determinism. NeN York: Harper and Row, 1966.

Bertrand, Louis. Baint Augustin. trans. Vincent O'gullivan New York: D. Appleton \& Co., 1914 .

Bourke, Vernon J. Augustine's quest of Wisdom. Kilwaukee, Wisc.: The Bruce Publishing Co., 1945.

Boyle, Joseph M., Germain Grisez, and Olaf Tollefsen. Free Choice: A Self-Referential Arqument. Notre Dame, Ind.: University of Notre Dame Press, 1976.

Brown, Peter. Augustine of Hippo. Berkeley, Calif.: University of California Press, 1967. 
Burnaby, John. Amor Dei: A study of the Religion of st. Augustine. Iondon: Hodder and stoughton, 1938.

Burton, M. I. The Problem of Evil: A Critique of Augustine's Point of View. Chicago: 1909.

Chadwick, Henry. Augustine. Oxford: Oxford University Press, 1986.

Chafer, Iewis sperry. Systematic Theology. Vol. I-III Dallas seminary/zondervan, 1947.

Copleston, F. C. A History of Philosophy: Medieval Philosophy: Augustine to scotus. Vol. II Nestminster, Md.: The Newman Press, 1957. 1974.

A History of Medieval Philosophy. New York: Harper and Row,

Craig, William Lane. Divine Foreknowledge and Future Contingency from Aristotle to suarez. Leiden: E.J. Brill, 1988.

- The anly Wise God: The Compatibility of Divine Foreknowledge and Human Freedom. Grand Rapids, Mich.: Baker Book House, 1987.

Davis, stephen T. ed. Encountering Evil: Iive Options in Theodicy. Atlanta: John Knox Press, 1981.

Dihle, Albrecht. The Theory of Will in Classical Antiguity. Berkeley, Calif.: University of California Press, 1982.

Erickson, Millard J. Christian Theology. Grand Rapids, Mich.: Baker Book House, 1983,84,85.

Evans, C. Stephen. Philosophy of Religion: Thinking About Faith. Downers Grove, Ill.: Inter Varsity Press, 1985.

Evans, G. R. Augustine on Evil. Cambridge: Cambridge University Press, 1982.

Geisler, Norman I. The Roots of Evil. Grand Rapids, Mich.: Zondervan/Probe, 1978.

Gilson, Etienne. The Christian Philosophy of Saint Augustine. trans. L.E.M. Lynch. New York: Random House 1960.

- A Gilson Reader. ed. Anton C. Pegis. Garden City, N.Y.: Image Books- Doubleday, 1957.

Griffin, David Ray. Cod, Power and Evil: A Process Theodicy. Philadelphia: Nestminster Press, 1976.

Hasker, William. God, Time, and Knowledge. Ithaca: Cornell University Press, 1989. 
Hick, John. Evil and the God of Love. revised ed. New York: Harper and Row, 1978.

- Philosophy of Religion. 2d ed. Englewood Cliffs, N.J.: Prentice Hall, 1973.

Jaspers, Rarl. Plato and Augustine. New York: Barcourt, Brace and world, 1957.

Jones, W.T. The Medieval Mind. 2d ed. New York: Harcourt, Brace and Forld, 1969.

Keenan, sister Mary Emily. The Life and Times of st. Augustine as Revealed in His Letters. Mashington D.C.: Catholic University Press, 1935.

Konyndyk, Kenneth. Introductory Modal Logic. Notre Dame, Ind.: University of Notre Dame Press, 1986.

Ieff, Gordon. Medieval Thought: St. Augustine to Oakham. Harmondsworth, kiddlesex, England: Penguin Books, 1958.

Iewis, C.8. The Problem of Pain. New York: Nacmillan, 1962.

Iovejoy, Arthur 0 . The Great Chain of Being. New York: Harper and Brothers, 1936/1960.

Meagher, Robert. Augustine: An Introduction. New York: Harper and Row, 1978.

Nash, Ronald H. Faith and Reason: searching for a Rational Faith. Grand Rapids, Mich.: Zondervan/Academie, 1988.

O'Connell, Robert J. Imagination and Metaphysics in Bt. Augustine. The Aquinas Lecture, 1986. Milwaukee, Wisc.: Marquette University Press, 1986.

- saint Augustine's Platonism. The saint Augustine Iecture, 1981 Villanova University Press, 1984

Pike, Nelson. ed. God and Evil. Englewood Cliffs, N.J.: Prentice Ball, 1964.

Plantinga, Alvin. God and Other Minds. Ithaca: Cornell University Press, 1967. - God, Freedam, and Evil. Grand Rapids, Kich.: William B. Eerdiman, 1974/1977.

Portalie, Eugene. A Guide to the Thought of Baint Augustine. trans. Ralph J. Bastian. Chicago: Henry Regenery Company, 1960. 
Reichenbach, Bruce R. Evil and a Good God. New York: Fordham University Press, 1982.

Roth, John K. Problems of the Philosophy of Religion. scranton, Pa.: Chandler Publishing Co., 1971.

suchocki, Marjorie Hewitt. The End of Evil: Process Eschatology in Historical context. New York: Btate Oniversity of New York Press, 1988.

Teselle, Eugene. Augustine the Theologian. Herder and Herder, 1970.

Trueblood, David Elton. Philosophy of Religion. Westport, Conn.: Greemood Press, 1957.

Van Inwagen, Peter. An Essay on Free Will. axford: Clarendon Press, 1983.

Warfield, Benjamin B. Calvin and Augustine. Philadelphia: Presbyterian and Reformed, 1956.

Watson, Gary. ed. Free Will. in Oxford Readings in Philosophy series. Oxford: axford University Press, 1982.

III. Articles

Adams, Marilyn Mccord. "Prablems of Evil: More Advice to Christian Philosophers." Faith and Philosophy 5 (1988) pp. 121-143.

- "Redemptive suffering: A Christian Approach to the Problem of Evil." In Rationality, Religious Belief, and voral Comitment, ed. Robert Audi and William J. Waimright pp. 248-267. Ithaca: Cornell University Press, 1986.

- "Theodicy Nithout Blame." Philosophical Topics 16 (Fall

1988) pp. 215-245.

Armstrong, A.H. "gt. Augustine and Christian Platonism." In Auqustine: a Collection of Critical Essays, ed. R.A. Narkus pP. 3-37 Garden City, N.Y.: Anchor Books/Doubleday, 1972.

Babcock, William S. "Augustine on Sin and Moral Agency." The Journal of Religious Ethics 16 (Bpring 1988) pp. 28-55.

- "Augrustine's Interpretation of Romans (A.D. 394-396)." Augustinian studies 10 (1979) pp. 55-74.

" "Focus on Augustine's Ethics: Introduction." The Jourmal of Religious Bthics 16 (Epring 1988) pp. 3-8.

Berthold, Fred. "Free Fill and Theodicy in Augustine: An Exposition and Critique." Religious studies 17 pp. 525-535. 
Brown, Robert F. "The First Evil Will vust Be Incomprehensible: A Critique of Augustine." Journal of the American Academy of Religion 46 pp. 315-329.

Burch, Robert. "The Defense from Plenitude against the Problem of Evil." International Journal for Philosophy of Religion 12 (1981) pp. 29-37.

Burns J. Patout. "Augustine on the Origin and Progress of Evil." The Jourmal of Reliqious Ethics 16 (spring 1988) pp. 9-27.

- "The Interpretation of Romans in the Pelagian Controversy." Augustinian studies 10 (1979) pp. 43-54.

Craig, William Iane. "Augustine on Forelnowledge and Free Will." Augustinian studies 15 (1984) pp. 41-63.

Cranz, F. E. 'The Develogment of Augustine's Ideas on society Before the Donatist Controversy." In Augustine: A Collection of Critical Essays, ed. R. A. Markus p. 336-403. Garden City, N.Y.: Anchor Books, 1972.

Crawford, Dan D. "Intellect and Will in Augustine's Confessions." Religious studies 24 (sept. 1988) pp. 291-302.

Decelles, David. "Divine Prescience and fluman Freedom in Augustine." Augustinian studies 8 (1977) pp. 151-160.

Flew, Antony. "Compatibilism, Free Will, and God." Philosophy 48 (1973) po. 231-244.

Hackstaff, L. H. "Translator's Introduction." In on the Free Choice of the Will. Indianapolis: Bobbs-Merrill Company, 1964. pp. ix-xocix.

Hopkins, Jasper. "Augustine on Foreknowledge and Free Will." International Jourmal for Philosophy of Religion 8 (1977) pp. 111-126.

Kane, G. Btanley. "Evil and Privation." International Journal for Philosophy of Religion 11 (1980) pp. 43-58.

- "The Failure of the soul-kaking Theodicy." International Journal for Philosophy of Religion 6 (Epring 1975) Pp. 1-22.

Raufman, Peter Iver. "The Iesson of Conversion: A Note on the question of Contimity in Augustine's Understanding of Grace and Human Will." Augustinian studies 11 (1980) pp. 49-64.

Lucas, J.R. "Pelagius and Augustine." The Journal of Theological studies New series 22 (April 1977) pp.73-85. 
Maker, William. "Augustine on Evil: The Dilemma of the Philosophers." Intermational Journal for Philosophy of Religion 15 (1984) pp. 149-160.

Nosher, David I. "gt. Augustine on Freedom." Crux 12 (1974-75) Pp. 18-29.

O'Brien, William J. "Toward Understanding Original sin in Augustine's Confessions." Thought 49 (1974) pp. 436-446.

O'Connell, Robert J. "De Libero Arbitrio I: stoicism Revisited." sugustinian studies 1 (1970) pp. 49-68.

O'Meara, John J. "The Neoplatonism of Saint Augustine." In Neoplatonism and Christian Thought, ed. Dominic J. O'Meara. Norfolk, Va.: International society for Neoplatonic studies, 1982. pp. 34-41.

Prendiville, John G. "The Develogment of the Idea of Habit in the Thought of saint Augustine." Traditio 28 (1972) pp. 29-99.

Rist, John M. "Augustine on Free Will and Predestination." In Augustine: a Collection of Critical Bssays, ed. R.A. Narkus. Garden City, N.Y.: Anchor Books/Doubleday, 1972. pp. 218-252.

Rowe, William I. "Augustine on Foreknowledge and Free Will." In Augustine: a Collection of Critical Essays, ed. R.A. Markus. Garden City, N.Y.: Anchor Books/Doubleday, 1972. pp. 209-217.

Sontag, Frederick. "Augustine's Metaphysics and Free Will." Harvard Theological Review 60 (1967) pp. 297-306.

stark, Judith Chelius. "The Problem of Evil: Augustine and Ricoeur." Augustinian studies 13 (1982) pp. 111-121.

Waimright, William J. "Christian Theism and the Free Will Defense: A Problem." International Jourmal for Philosophy of Religion 6 (1975) Pp. 243-250.

Warfield, Benjamin B. "Introductory Bssay on Augustine and the Pelagian Controversy." In Phillip schaff ed. A select fibrary of Nicene and Post-Nicene Fathers, First series Vol. V New York: 1887-1902; reprint Grand Rapids, Kich.: Nm. B. Eerdmans, 1987 pp. xili-1xxi.

IV. Unpublished Forks

Young, William. History of Christian Thought. Unpublished class notes. The University of Rhode Island. 